\title{
Atmospheric River-Induced Precipitation and Snowpack during the Western United States Cold Season
}

\author{
Hisham Eldardiry, Asif Mahmood, Xiaodong Chen, Faisal Hossain, and Bart Nisssen \\ Department of Civil and Environmental Engineering, University of Washington, Seattle, Washington \\ DENNIS P. LETTENMAIER \\ Department of Geography, University of California, Los Angeles, Los Angeles, California
}

(Manuscript received 24 October 2018, in final form 3 February 2019)

\begin{abstract}
Atmospheric rivers (ARs) are narrow, elongated corridors of high water vapor content transported from tropical and/or extratropical cyclones. We characterize precipitation and snow water equivalent associated with ARs intersecting the western U.S. coast during the cold season (November- March) of water years 19492015. For each AR landfalling date, we retrieved the precipitation and relevant hydrometeorological variables from dynamically downscaled atmospheric reanalyses (NCEP-NCAR) using the WRF mesoscale numerical weather prediction model. Landfalling ARs resulted in higher precipitation amounts throughout the domain than did non-AR storms. ARs contributed the most extreme precipitation events during January and February. Daily snow water equivalent (SWE) changes during ARs indicate that high positive net snow accumulation conditions accompany ARs in December, January, and February. We also assess the historical impact of AR storm duration and precipitation frequency by considering the precipitation depth estimated during a 72-h window bounding the AR landfall date. More extreme precipitation amounts are produced by ARs in the South Cascades and Sierra Nevada ranges compared with ARs with landfall farther north. Most AR extreme precipitation events (and lower SWE accumulations) are produced during warm AR dates, especially toward the northern end of our domain. Analysis of ARs during dry and wet years reveals that ARs during wet years are more frequent and produce heavier precipitation and snow accumulation as compared with dry years. Such conditions are evident in drought events that are associated with a reduced frequency of ARs.
\end{abstract}

\section{Introduction}

Atmospheric rivers (ARs) are narrow, elongated corridors of high water vapor content transported from tropical and/or extratropical cyclones (Browning and Pardoe 1973; Zhu and Newell 1998; Bao et al. 2006; Neiman et al. 2008; Ralph and Dettinger 2011; EirasBarca et al. 2018; Ralph et al. 2018). When an AR event makes landfall, the transport of large amounts of water vapor can lead to heavy precipitation and sometimes flooding, especially if the moisture-laden air is forced to rise rapidly over a mountain barrier (Dettinger et al. 2011). For instance, in January 2017, an AR event in Northern California produced powerful storms and resulted in extensive flooding and triggered power outages and mudslides (Rosen 2017). Such heavy storms bring challenges to water managers operating dams whose

\footnotetext{
Corresponding author: Faisal Hossain, fhossain@uw.edu
}

operating purposes include flood risk reduction. Thus, better management strategies for water resources in the western United States are needed to cope with the expected increase in AR-induced precipitation as the climate continues to change (Hagos et al. 2016; Dettinger 2011).

Several studies have highlighted the importance of ARs and their connection with heavy precipitation and flooding across the western United States (Ralph et al. 2006; Neiman et al. 2008, 2011; Barth et al. 2017; Konrad and Dettinger 2017; Lamjiri et al. 2017). For instance, Ralph et al. (2006) used observations from an 8-yr series of field observations combined with satellite observations in Northern California to explore the possible role of ARs in generating precipitation that led to flood events in the Russian River basin. They concluded that AR conditions caused heavy rainfall as a result of orographically enhanced precipitation for all major flooding events. Barth et al. (2017) examined the fractional contribution of ARs on annual peak flows in the western 
United States and concluded that the highest fraction $(80 \%-100 \%)$ of AR-generated peaks occurred in the Pacific Northwest and along the Northern California coast. Young et al. (2017) examined the relationship between flood events and ARs in California for water years 2005-14 using a catalog of landfalling ARs produced by Rutz et al. (2014). Their results indicated that most of the high-impact events related to floods and debris flows were associated with cold season ARs with landfall in Northern California.

While it is widely known that most major flooding events across the coastal western United States are driven by ARs, multidecadal characteristics of ARinduced precipitation and snowpack changes have not yet been fully documented. Recently, Lamjiri et al. (2017) studied the contribution of ARs to major storm precipitation along the U.S. West Coast. They concluded that ARs are longer in duration and have higher-than-average intensities as compared with nonAR storms. Here, we explore the intraseasonal variability of precipitation as well as snow water equivalent (SWE) changes during cold season ARs. We provide a comprehensive analysis of cold season landfalling AR dates (November-March) that generated heavy rainfall in the coastal western United States over the period 1949-2015. We also evaluate changes in SWE associated with AR events over the same period. Snowmelt can exacerbate the direct effects of extreme precipitation and is a particularly important consideration given recently observed trends toward earlier snowmelt across the region (Cayan et al. 2001; Regonda et al. 2005; Trujillo and Molotch 2014). In addition, the relationship among land surface hydrometeorological variables, including precipitation, snowpack changes, and associated surface temperature during AR events has received relatively little attention in past studies. Guan et al. (2010) observed negative correlations between SWE change and surface air temperature across the Sierra Nevada. However, considering the Sierra Nevada as one region could mask spatial differences in SWEtemperature relationships. Here, we extend the analysis of Guan et al. (2010) to include the entire coastal western United States from Northern California to the Canadian border and consider the relationship with temperature at different AR landfalling latitudes.

The questions that motivate our study are 1) how do precipitation and snowpack changes induced by ARs vary across the cold season and how do the hydrologic signatures of ARs differ along a latitudinal transect through the Pacific maritime region of the western United States, and 2) how do precipitation and SWE changes vary for ARs during dry versus wet years and for ARs associated with warm conditions? To address these questions, we retrieved hydrometeorological outputs from dynamically downscaled atmospheric reanalyses (NCEP-NCAR) using the Advanced Research version of the Weather Research and Forecast (WRFARW) Model over the period 1949-2015. We use WRF downscaling with National Centers for Environmental Prediction-National Center for Atmospheric Research (NCEP-NCAR) boundary conditions to capture regional precipitation intensity and spatial variability that otherwise is poorly represented by coarse-resolution reanalysis data, especially over complex terrain (LorentePlazas et al. 2018). We incorporate in our analysis the relationships among frequently observed hydrometeorological variables, including precipitation, surface air temperature, and SWE.

Our characterizations are intended to lay the background for subsequent investigation into the role of AR events and associated hydrologic controls on catastrophic flooding. Addressing such questions has implications for managing water resources and mitigating AR-related flood and drought events in the western United States. Griffin and Anchukaitis (2014) and Swain et al. (2014), for example, discussed ARs as relevant to the severe California drought conditions in 2012-14. The remainder of the paper is organized as follows: we summarize the data sources and methods applied in section 2 , with results and discussion in section 3 , and concluding remarks are in section 4.

\section{Data sources and methods}

\section{a. Atmospheric river catalog}

Methods that have been used to identify ARs are generally based on thresholding integrated water vapor (IWV) or integrated water vapor transport (IVT), tracking spatial features in a moisture-related field, and setting specific criteria for AR length, orientation, and intensity (Ralph et al. 2004; Neiman et al. 2008; Ralph et al. 2013; Nayak et al. 2014; Guan and Waliser 2015). A more comparative framework is provided by the Atmospheric River Tracking Method Intercomparison Project (ARTMIP; Shields et al. 2018), which assesses the relative performance of AR identification methods and quantifies sources of uncertainties in AR algorithms.

Following the criteria defined by Guan and Waliser (2015), we characterize ARs as having IVT intensity of more than $100 \mathrm{~kg} \mathrm{~m}^{-1} \mathrm{~s}^{-1}$ or the 85th percentile (whichever is greater) between 1000 and $300 \mathrm{hPa}$ and with the geometry requirements of length $>2000 \mathrm{~km}$ and length/ width ratio $>2$. Ralph et al. (2019) show a good agreement in detecting AR characteristics (e.g., frequency and duration) when comparing the Guan and Waliser (2015) 


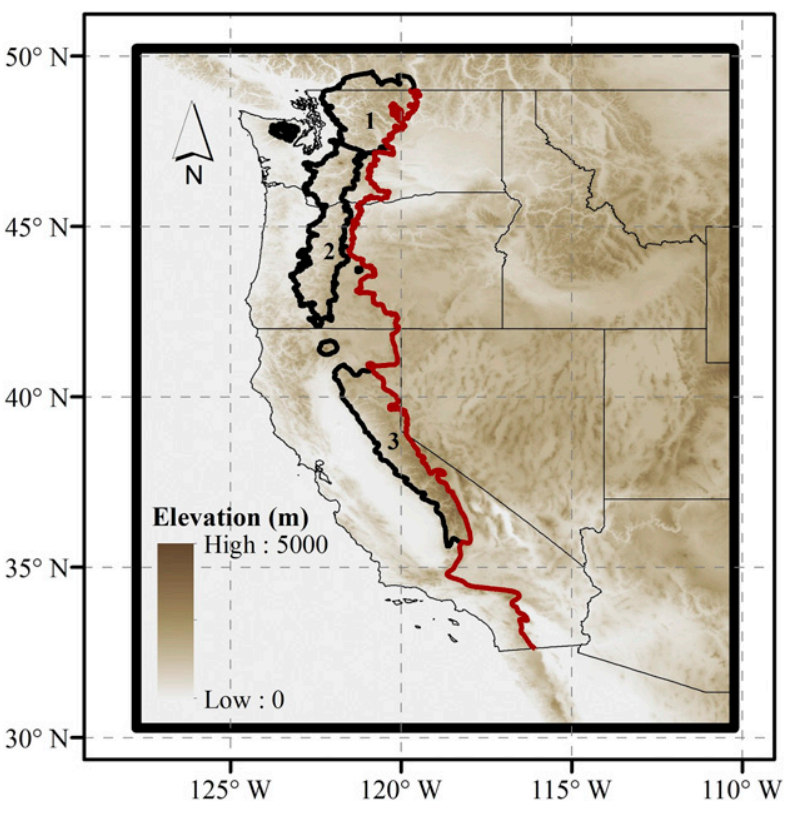

FIG. 1. WRF model domain covering the western United States (solid black box) and the three study subregions delineated using the Commission for Environmental Cooperation Ecological regions of North America, Level III (McMahon et al. 2001; Omernik 2004): 1) North Cascades, 2) South Cascades, and 3) Sierra Nevada. The red line represents the inland boundary of the coastal domain considered in our analysis.

method with other IVT-based algorithms (e.g., Gershunov et al. 2017; Rutz et al. 2014). Here, we used the IVTbased AR catalog produced by Guan and Waliser (2015) using the NCEP-NCAR reanalysis for the 67-yr period of water years 1949-2015.

We compared the ARs in the Guan and Waliser (2015) catalog with the AR record published in Neiman et al. (2008) (hereinafter referred to as the Neiman catalog) which is based on IWV observed by the Special Sensor Microwave Imager/Sounder (SSM/I) satellites for the period of overlapping water years 1998-2008 [the Neiman catalog was extended through 2008 by Dettinger et al. (2011)]. The Neiman catalog using SSM/I generally provides the most reliable identification of ARs and has been evaluated in many AR studies (Ralph et al. 2006; Guan et al. 2010; Ralph and Dettinger 2012). We determined the percentage of agreement between the two catalogs for two sets of AR dates: 1) north coastal AR dates (NAR), where the north coast is defined as the Washington, Oregon, and British Columbia coasts (from $41.0^{\circ}$ to $52.5^{\circ} \mathrm{N}$ ), and 2) south coastal AR dates (SAR), where the south coast is defined as the California coast between $32.5^{\circ}$ and $41.0^{\circ} \mathrm{N}$ (Fig. 1). Table 1 shows the percentage of agreement between the Neiman and Guan-Waliser dates for NAR and SAR dates during the common detection period
TABLE 1. Agreement between the Neiman AR catalog and the NCEP-NCAR catalog for cold seasons during the common detection period (water years 1998-2008). NAR (SAR) is the northern (southern) AR region, north (south) of $41^{\circ} \mathrm{N}$ latitude.

\begin{tabular}{lccc}
\hline \hline & $\begin{array}{c}\text { NAR } \\
\text { agreement (\%) }\end{array}$ & $\begin{array}{c}\text { SAR } \\
\text { agreement }(\%)\end{array}$ & $\begin{array}{c}\text { (NAR + SAR) } \\
\text { agreement }(\%)\end{array}$ \\
\hline \pm day & 87 & 76 & 82 \\
\pm 1 day & 95 & 87 & 91 \\
\pm 2 day & 95 & 88 & 91 \\
\hline
\end{tabular}

(water years 1998-2008). We computed the agreement percentage as the ratio between number of ARs identified in the two catalogs for NAR, SAR, and the total AR dates, that is, summing NAR and SAR dates (Table 1). We allowed an offset of \pm 1 and \pm 2 days to account for differences in timing between the two algorithms. The agreement percentage for NAR dates was about $95 \%$ when allowing a \pm 1 day offset. When comparing the total number (union) of AR dates (i.e., NAR + SAR), the Guan-Waliser catalog captures $91 \%$ of the Neiman AR dates with \pm 2 days of offset. Based on the relatively high degree of coincidence of AR dates in the overlap period, and because the Guan-Waliser catalog spans many more years (hence better supports statistical analyses of the type we performed here), we adopted the Guan-Waliser catalog as the basis for our study.

We characterized precipitation and SWE changes separately for ARs in $2.5^{\circ}$ latitudinal bands at their intersections with the U.S. Pacific coast from just north of the Canadian border south to $30^{\circ} \mathrm{N}$. The use of $2.5^{\circ}$ latitudinal bands matches the spatial scale provided by the Guan-Waliser AR catalog $\left(2.5^{\circ} \times 2.5^{\circ}\right)$. We focused our analysis on events during the cold season from November through March when ARs are associated with water vapor fluxes sufficient to produce extreme precipitation (Neiman et al. 2008; Lamjiri et al. 2017; Young et al. 2017). Figure 2 shows the monthly distribution of cold season landfalling ARs (4315 dates using Guan-Waliser catalog) during water years (19492015). As shown in Fig. 2, a larger number of AR dates are identified in northern latitudes, for example, at $45^{\circ}$ and $50^{\circ} \mathrm{N}$, compared to southern latitudes with November receiving the largest number of dates (1206) followed by December (1073). The largest number of AR dates for southern landfalling latitudes (south of $37.5^{\circ} \mathrm{N}$ ) were identified in January. Similar AR frequency results were also reported by Rutz et al. (2014), with November and January having the highest number of AR dates over the northern half of the western United States and Southern California, respectively. 


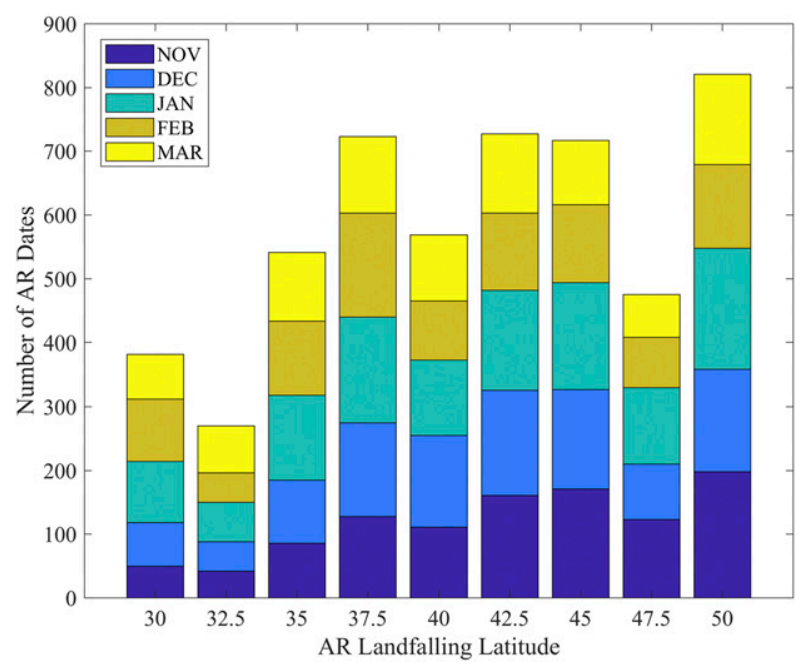

FIG. 2. Number of all AR dates for each month during the wintertime season (November-March) using the NCEP-NCAR AR catalog.

\section{b. WRF downscaling}

For each AR landfalling date, we retrieved the precipitation and relevant hydrometeorological variables produced through dynamic downscaling (via WRF version 3.7.1; Skamarock et al. 2005) of the NCEP-NCAR atmospheric reanalysis which is available at a 6-hourly temporal resolution and $2.5^{\circ}$ latitude-longitude spatial resolution (Kalnay et al. 1996; Kistler et al. 2001). Our approach for dynamic downscaling is essentially identical to that used by Chen and Hossain (2016) who relied on the same NCEP-NCAR reanalysis products as initial and boundary conditions for reconstructing historical extreme storms between 1948 and 1979.

We performed our WRF simulations over a single domain, that is, without nesting, an approach that has been used successfully in previous studies at various horizontal resolutions (e.g., Wang and Kotamarthi 2014; Liu et al. 2017; Hu et al. 2018). For instance, Wang and Kotamarthi (2014) showed that the dynamic downscaling of $2.5^{\circ}$ NCEP-DOE Reanalysis II data at a $12-\mathrm{km}$ single WRF domain is adequate to capture spatial patterns and annual cycles of air temperature and precipitation over most of the contiguous United States. Our domain covered the western United States with a grid resolution of $15 \mathrm{~km}$ (Fig. 1). The WRF physics options we selected included the Morrison double-moment scheme (Morrison et al. 2009) (option 10) for microphysics, and Kain-Fritsch (Kain and Fritsch 1990, 1993; Kain 2004) (option 1) for the cumulus physics. We selected the Yonsei University (YSU; Hong et al. 2006) as the planetary boundary layer scheme. We used the Noah-MP (version 1.6) land surface model with Monin-Obukhov (option 1) for the surface layer drag coefficient calculation, the CLASS option for ground surface albedo, and the Jordan (1991) model (option 1) for precipitation partitioning between snow and rain. These land surface parameters, which affect the model's accumulation and ablation of SWE, are recommended by Niu et al. (2011) and Yang et al. (2011). We ran the simulations at a time step of $90 \mathrm{~s}$ for each year of the study period (1949-2015) and produced hourly output variables between 0000 UTC 15 October and 0000 UTC 1 April. The first 15 days of outputs were discarded as model spinup. For the purpose of our analysis, we archived the following hourly variables: precipitation, SWE, and instantaneous temperature at 2-m height above the surface.

The set of WRF parameterization schemes we selected have demonstrated plausible performance in reproducing precipitation amounts over the Pacific Northwest and California (Chen and Hossain 2016; Chen et al. 2017). In addition, we opted to base our analysis on WRF output rather than datasets derived directly from observations (e.g., gridded precipitation and temperature fields) to avoid problems associated with variability in gauge density, especially at high elevations. Sparse precipitation (and temperature) gauge coverage is especially problematic at high elevations, where most of the precipitation occurs in our study domain.

We compared the daily SWE from WRF simulations with the SWE output from Livneh et al. (2013, hereafter L2013). The L2013 dataset was generated using the Variable Infiltration Capacity (VIC) hydrologic model, version 4.1.2 (Liang et al. 1994), forced with a dataset of gridded precipitation, and temperature adjusted for orographic variations using a climatology from the Parameter-Elevation Regressions on Independent Slopes Model (PRISM; Daly et al. 1994). SWE from 1 April was used as a surrogate for the total seasonal snow accumulation (after the end of the cold season). Figure 3 shows a scatterplot for 1 April SWE as simulated by the WRF and VIC models for the three mountainous subregions shown in Fig. 1: 1) North Cascades, 2) South Cascades, and 3) Sierra Nevada. We selected these subregions because they all have substantial orographic relief, and the mountain divides are relatively close to the coast. We delineated their boundaries based on the Commission for Environmental Cooperation Ecological Regions of North America, Level III (McMahon et al. 2001; Omernik 2004). WRF and L2013 agree well for the Sierra Nevada. However, WRF produces slightly lower values in the North and South Cascades subregions. This higher daily SWE from VIC model has also been reported by L2013 and Maurer et al. (2002), who produced a predecessor 


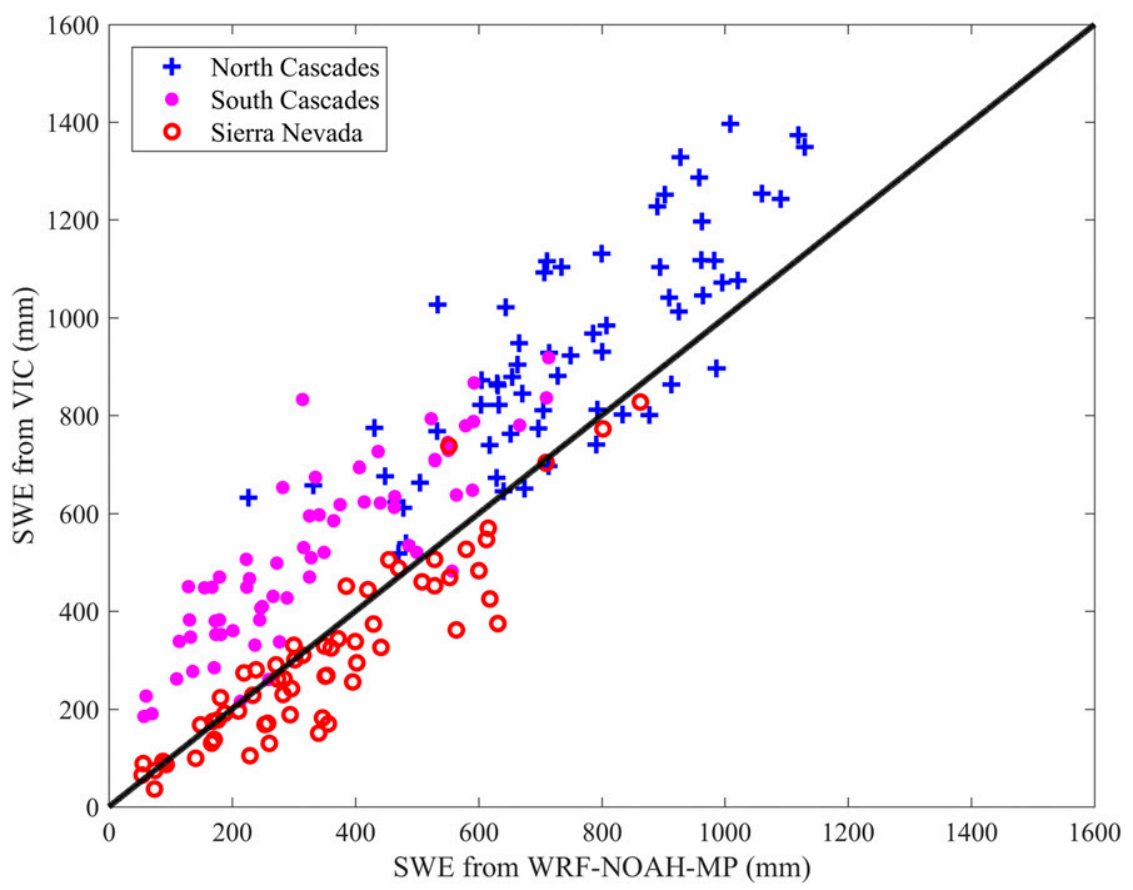

FIG. 3. Scatterplots for $1 \mathrm{Apr}$ SWE as simulated by the WRF Noah-MP and VIC models for the 67-yr period (1949-2015) and averaged over three mountainous subregions: North Cascades, South Cascades, and Sierra Nevada.

dataset to L2013, when compared to snow observations over some mountainous regions of the western United States including the Cascades. Based on these comparisons and the previous referenced work, we conclude that the WRF simulations perform plausibly well relative to independent model- and observation-based SWE estimates.

\section{c. Analysis approach}

We characterized precipitation and snowpack during dates of AR landfalls as follows:

1) We aggregated the hourly precipitation and SWE change from WRF to daily amounts on the calendar date of each AR (based on Guan-Waliser catalog). We performed these aggregations for each month considering only the AR landfall dates. We then calculated the AR daily precipitation (or SWE change) for each WRF grid cell by considering the maximum daily estimate during a 72 -h window bounding the AR landfall date (i.e., one day before and after the AR date). We defined high-impact AR dates as corresponding to ARs with upper 10th percentile daily precipitation (or SWE change) for each month of the cold season (November-March). Peterson et al. (2008) showed that analysis of extremes farther out on the tails of the distribution (e.g., 95th percentile) result in similar changes in extremes as using the upper 10th percentiles. We used the average of the upper 10th percentile precipitation (and SWE) as a way to represent AR dates with large precipitation (and SWE). In addition, we assessed the severity of AR-induced precipitation by quantifying the fraction of AR dates from all dates producing the upper 10th percentile of daily precipitation (considering all dates and not only AR dates) for each latitudinal band. In analyzing the SWE changes for each grid cell, we treated positive and negative changes separately to indicate the snow accumulation and snowmelt associated with each AR date.

2) We evaluated the impact of AR storm duration and frequency on precipitation depth over the three subregions (Fig. 1) using $2.5^{\circ}$ latitudinal bands within which the AR landfalling latitude (retrieved from the Guan-Waliser catalog) was located. To address the frequency of AR-induced precipitation, we constructed a precipitation series of AR dates for each WRF grid by selecting the AR dates with maximum precipitation in the cold season of each year (sample size $=67$ out of 4315 total AR dates). We calculated precipitation amounts for each AR date for different durations using hourly precipitation accumulations from WRF outputs. The durations ranged from one 


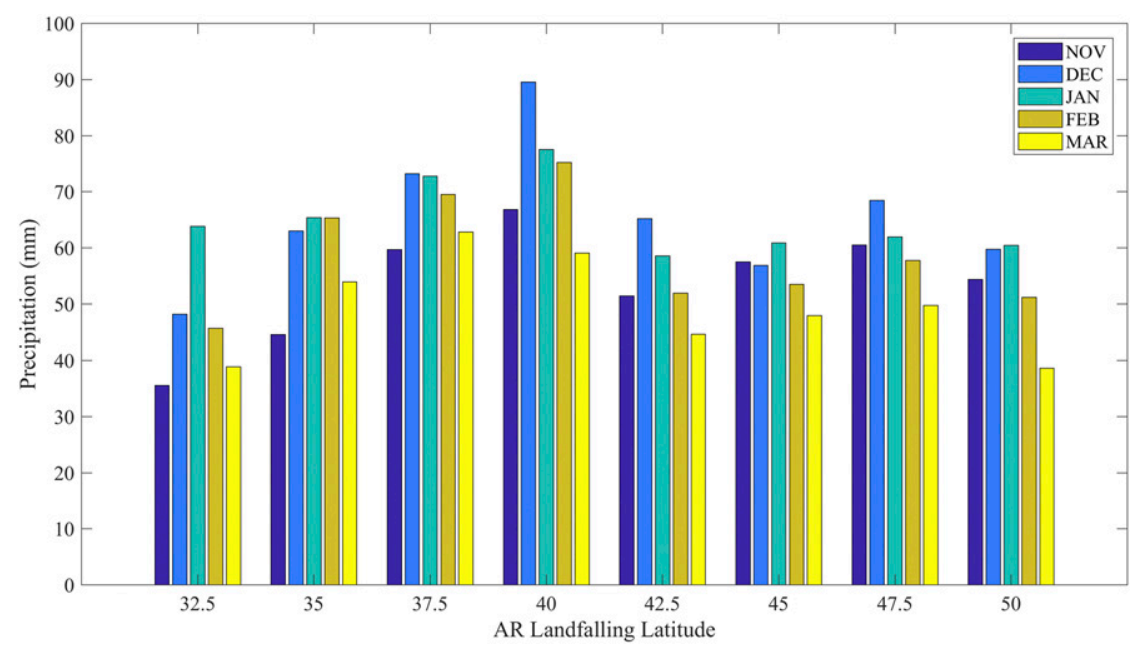

FIG. 4. The precipitation threshold used to identify high-impact AR dates (or the 90th percentile precipitation) for each latitudinal band by cold season month.

hour (duration of the maximum precipitation in the AR event), to three days enveloping the AR event date, that is, one day before and one day after the nominal AR date (the dates of AR landfall were identified as described in section $2 \mathrm{a}$ ). We also calculated the precipitation associated with an AR event as the maximum precipitation for $n$ consecutive hours out of 72 (3-day window), where $n$ is the duration of the event (and $n=1,2,3,6,12,24,48$, $72 \mathrm{~h}$ ). We then fitted the precipitation series for each grid to the generalized extreme value (GEV) distribution using the L-moment method of Hosking and Wallis (1997). The GEV distribution has been widely applied for predicting hydrologic and meteorological extremes (e.g., Overeem et al. 2009; Eldardiry et al. 2015). We estimated the frequency of each event by converting the cumulative probability of each event into return periods $[T=1 /(1-P)]$, where $T$ is the return period and $P$ is the cumulative probability of an AR event.

3) We partitioned ARs into dry versus wet years. To do so, we ranked the accumulated winter (NovemberMarch) precipitation over our study period, and defined dry years as being in the lower 10th percentile, and wet years in the upper 10th percentile. We then calculated the AR-induced daily precipitation and SWE changes for each month of the dry and wet years.

4) Finally, we analyzed the changes in precipitation depth and SWE change with surface air temperature. We performed this analysis by considering the warm events as being associated with the AR dates with upper 10th percentile daily precipitation (or SWE change). We first identified the AR dates resulting in the upper 10th percentile daily precipitation (or SWE change) and then we defined warm events as the $20 \%$ of these AR dates with the highest surface air temperature. We used the $20 \%$ threshold as a way to represent the warm AR dates with the highest surface temperature (we tested other threshold values, for example, $30 \%$, and we did not find much difference compared to our $20 \%$ threshold).

We present our results for snowpack characterization at a regional scale for the three mountainous subregions. In addition, to account for the elevation effects on snowpack, we used elevation bands with 500 -m vertical intervals using the ETOPO1 elevation dataset constructed at 1-arc-min resolution (Amante and Eakins 2009).

\section{Results}

\section{a. Precipitation}

The high-impact AR dates are defined as dates corresponding to ARs with upper 10th percentile daily precipitation for each month of the cold season (November-March). Some AR dates had little or no precipitation and only about $10 \%$ of the ARs (449) contribute to the upper 10th percentile precipitation. Figure 4 shows the threshold used to identify the high-impact AR dates (or the 90th percentile precipitation) at different latitudinal bands. The precipitation thresholds are higher in the southern landfalling latitudes over the Sierra Nevada (between $32.5^{\circ}$ and $40^{\circ} \mathrm{N}$ ) with maximum 90th percentile at $40^{\circ} \mathrm{N}$ in December $\left(90 \mathrm{~mm} \mathrm{day}^{-1}\right)$. Figure 5 shows the average values of the upper 10th percentile of daily precipitation produced by all ARs. The precipitation 

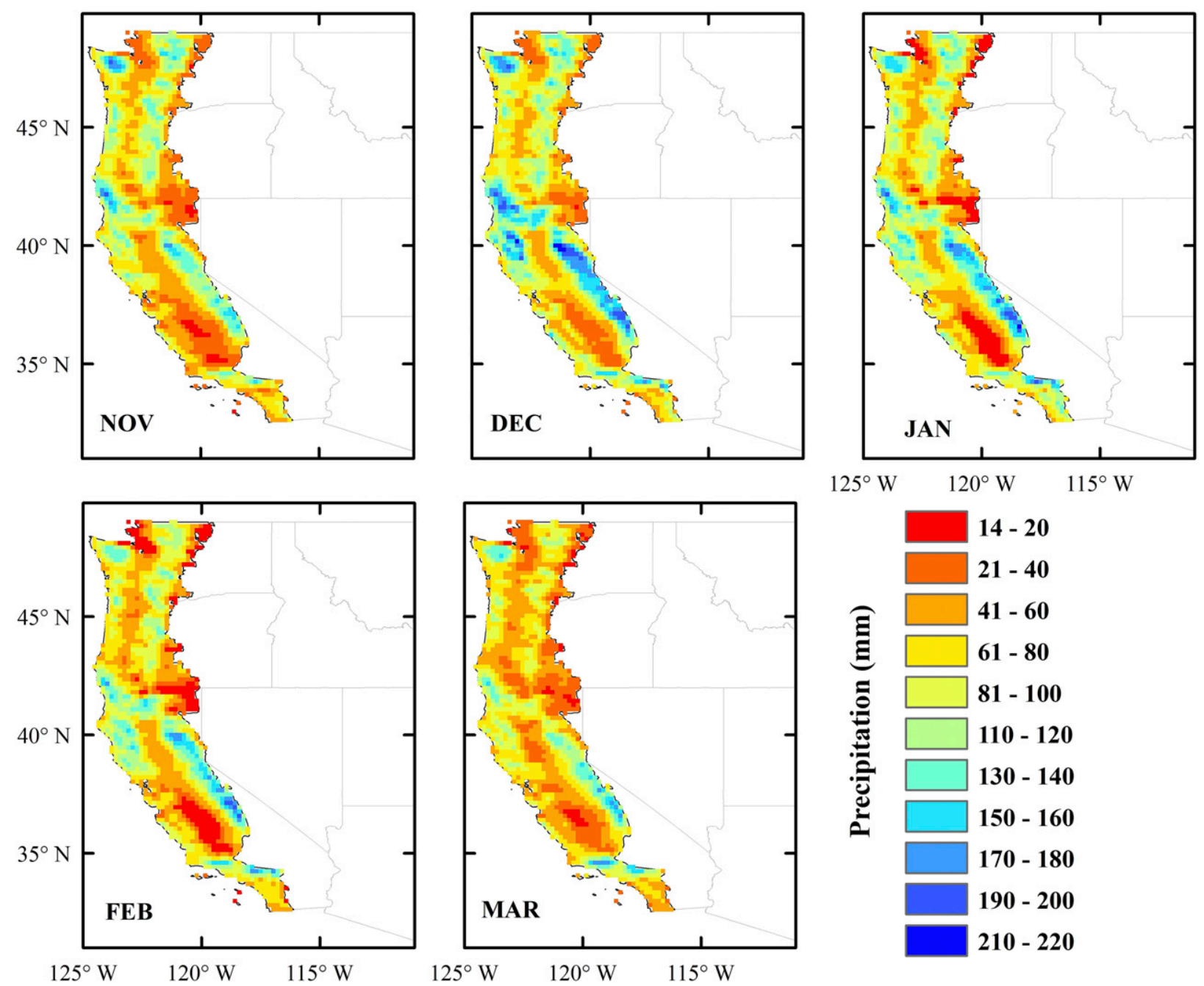

$125^{\circ} \mathrm{W}$

$120^{\circ} \mathrm{W}$

$115^{\circ} \mathrm{W}$

FIG. 5. The average of upper 10th percentile daily precipitation over the western coastal domain during the winter (November-March) ARs for water years 1949-2015 (precipitation amounts less than $14 \mathrm{~mm}$ are displayed in white).

associated with the AR events covers most of California to (and slightly beyond) the Sierra Nevada crest and western Washington and Oregon about to the Cascade crest. The maximum daily precipitation from these events occurs mostly in December and January in the Sierra Nevada subregion with many grid cells there having events that average over $160 \mathrm{~mm}$. Event averages tend to decline northward (e.g., to an average of $84 \mathrm{~mm}$ for the North Cascades), although the number of AR events increases at northern latitudes (Fig. 2) with an anomaly for the band centered at $47.5^{\circ} \mathrm{N}$, which may be associated with the rain shadow from the Olympic Mountains.

Figure 6 shows the fraction of the upper 10th percentile precipitation that is produced by AR events in each latitude band by month. The AR fractions vary temporally (across different months) and spatially (across different landfalling latitudes), with a local maximum in February (AR fraction $=0.90$ or $90 \%$ of upper 10th percentile precipitation is produced by AR events) at $37.5^{\circ} \mathrm{N}$, which covers most of the central part of the Sierra Nevada subregion. At all southern landfalling latitudes (from $30^{\circ}$ to $42.5^{\circ} \mathrm{N}$ ), January and February have the largest AR fraction that resulted in the upper 10th percentile precipitation. This seasonality in extreme precipitation produced by AR dates is comparable to the seasonality of AR IVT maxima studied by Dettinger et al. (2018). They found that more extreme AR IVT occurs early in the cold season (November and December) in northern latitudes (north of $40^{\circ} \mathrm{N}$ ). The maximum IVT values then migrate farther south by midwinter (January and February). AR-related extreme precipitation in southern latitudes along the Sierra Nevada was also explored by Young et al. (2017) 


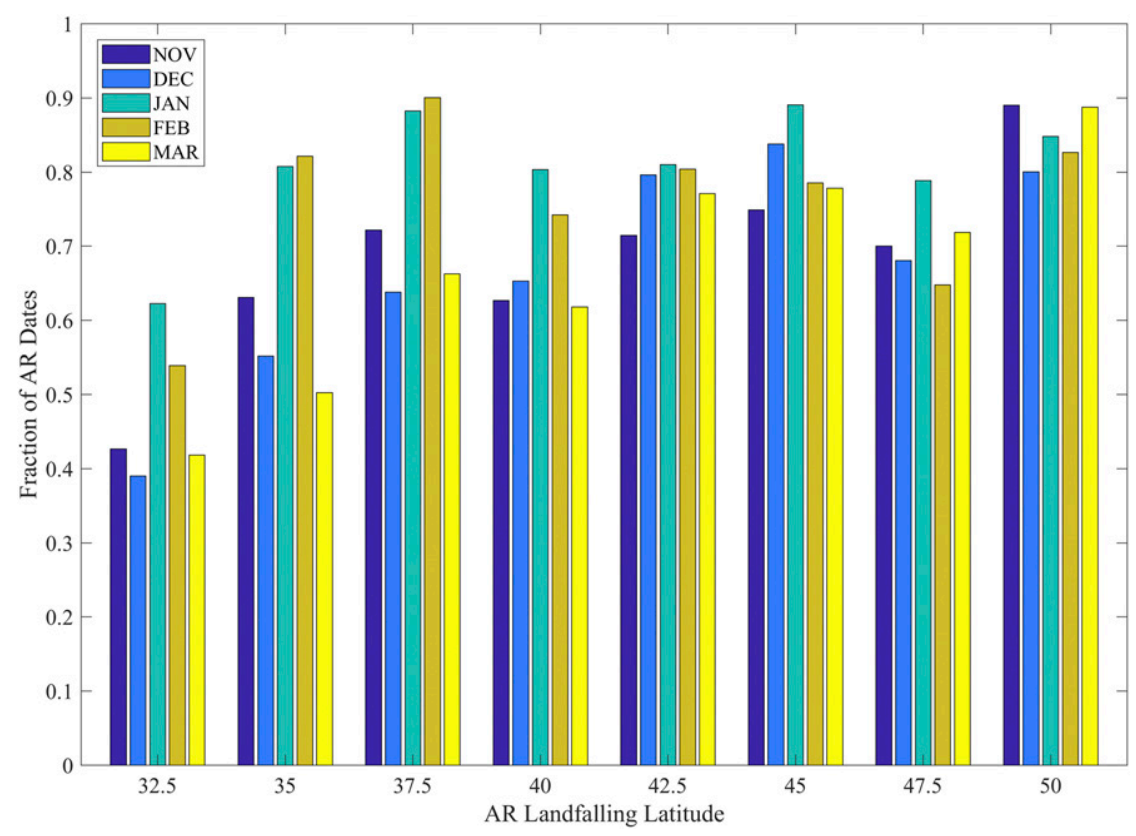

FIG. 6. Fraction of AR dates from all dates producing the upper 10th percentile of daily precipitation for each latitudinal band by cold season month.

who found that 2-day precipitation associated with ARs was generally ranked in the upper $5 \%$ of all such events (AR and non-AR) during water years 2005-14.

We used depth-duration-frequency (DDF) analysis for the three subregions shown in Fig. 1 to account for the impact of AR storm duration on precipitation depth and frequency. At each grid cell, we used a parametric approach in which we estimated quantiles from fitted GEV distributions using the L-moment method (Hosking and Wallis 1997). Figure 7 shows the resulting precipitation depths and frequencies at 1- and 3-day durations for the three subregions. Higher precipitation amounts are produced by ARs making landfall at southern latitudes, that is, the Sierra Nevada subregion, across a range of durations (only 1- and 3-day durations are shown in Fig. 7) and return periods. During AR dates along the Sierra Nevada, larger relative changes in precipitation amounts occur between lowand high-return periods, for example, 2 years versus 100 years (Fig. 7a), especially at the areas bounding the AR landfalling at $37.5^{\circ} \mathrm{N}$. The larger relative changes for precipitation (e.g., ratio of the 100- to 2-yr events) are associated with more highly skewed GEV distributions, with maximum ratios near $37.5^{\circ}$ and $40.0^{\circ} \mathrm{N}$. For instance, the 3-day AR-induced precipitation along the Sierra Nevada subregion for the 2- and 100-yr return periods ranges from 176 to $512 \mathrm{~mm}$ (representing $109 \%$ and $318 \%$ of the mean maximum precipitation,
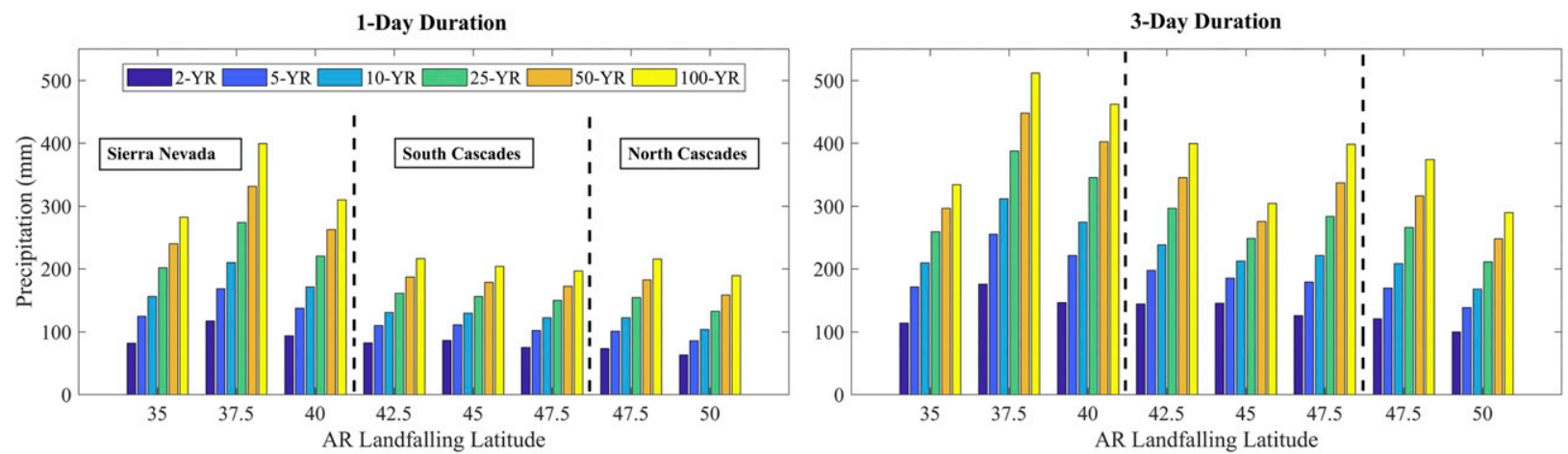

FIG. 7. (left) The 1-day AR precipitation depths and frequencies by AR landfalling latitude (return periods are indicated by different colors). (right) As in the left panel, but for 3-day totals. 

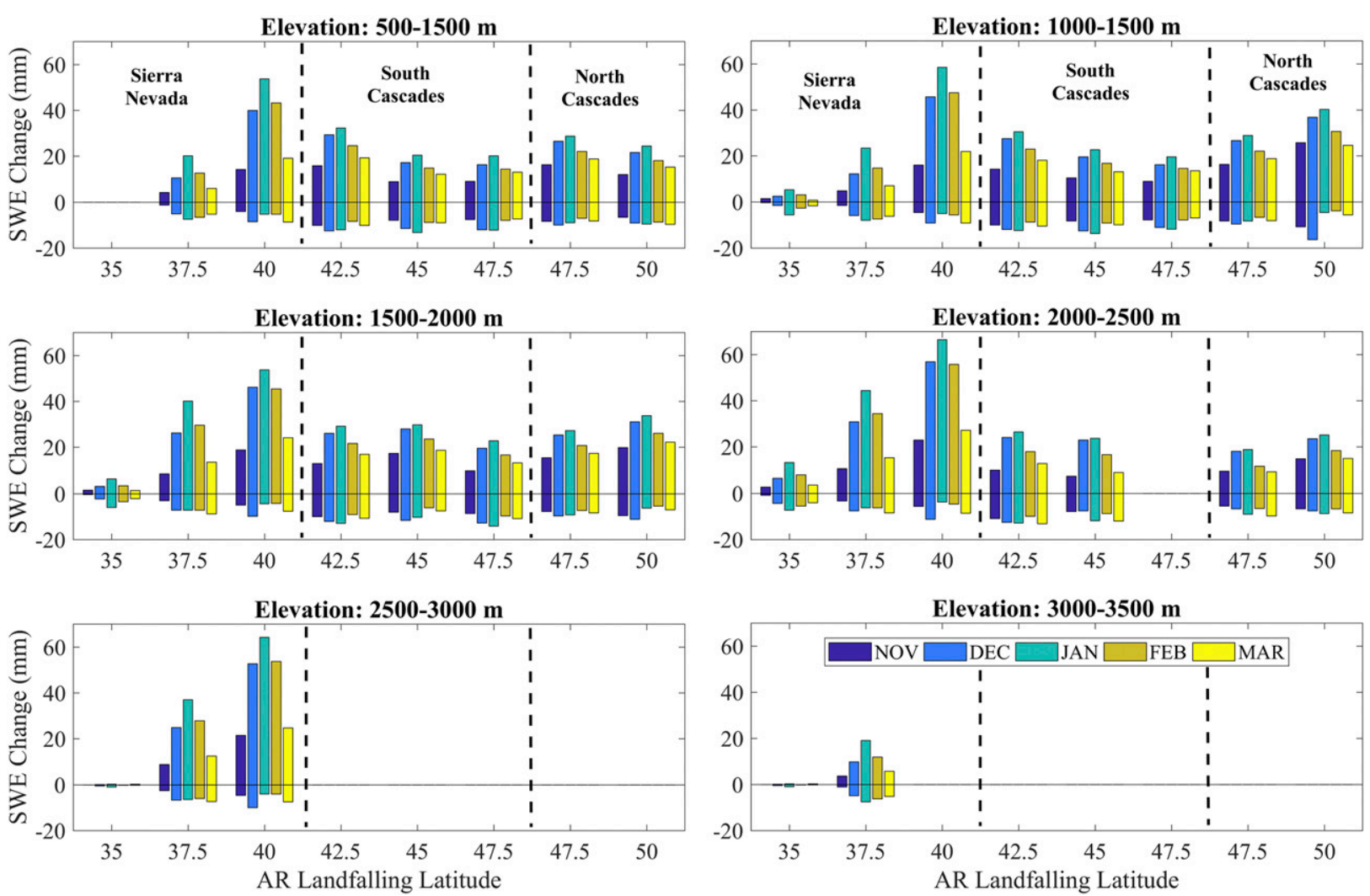

FIG. 8. Average of upper 10th percentile positive and negative changes in daily SWE during the upper 10th percentile of daily precipitation on AR dates by winter month. Daily SWE changes are calculated at the AR landfalling latitudes crossing the domain as shown in Fig. 1 for different elevation bands (zero SWE change represents no snow observed or that no elevation band exists in the subregion).

respectively) at $37.5^{\circ} \mathrm{N}$, whereas the precipitation depth for the same return periods ranges from 100 to $290 \mathrm{~mm}$ (representing $74 \%$ and $215 \%$ of the mean maximum precipitation) at $50^{\circ} \mathrm{N}$ (North Cascades).

\section{b. SWE change}

We classified the AR dates into ARs producing snow accumulation or snowmelt by separating the daily SWE changes into positive or negative values for each AR date. We calculated the AR-induced SWE change by elevation bands (500-m intervals). We considered the elevation bands from 500 to $3500 \mathrm{~m}$ for the three subregions (note that higher-elevation bands, between 2500 and $3500 \mathrm{~m}$, exist only over the Sierra Nevada). We also considered only ARs that produced SWE changes in the upper 10th percentile of all AR-related positive and negative SWE changes (considering only the absolute magnitude of SWE changes, that is, the upper 10th percentile of negative SWE changes contains the largest snowmelt magnitudes). Figure 8 shows daily positive and negative SWE changes which reflect the variations in snowfall and snowmelt, respectively. The upper 10th percentile ARs dominantly result in snow accumulations across all subregions compared to snowmelt (negative SWE changes). We also observed increases in SWE for more intense ARs representing the upper 5 th percentile (figure not shown). For all AR landfalling latitudes and across elevation bands, the highest positive SWE changes occur in January. The Sierra Nevada subregion had the highest positive SWE changes at $40^{\circ} \mathrm{N}$ at different elevation bands compared to the North Cascades and South Cascades subregions. For instance, snow accumulation occurring during cold season AR dates is greatest in January in the Sierra Nevada subregion at $40^{\circ} \mathrm{N}$ and elevation band 2000 $2500 \mathrm{~m}$ with an average daily SWE of $67 \mathrm{~mm}$. Along the Sierra Nevada range, higher snowfall is produced by ARs falling at the northernmost latitudinal band $\left(40^{\circ} \mathrm{N}\right)$ compared to southernmost band $\left(35^{\circ} \mathrm{N}\right)$. A similar result was reported by Huning et al. (2019) who concluded higher magnitudes of AR cumulative snowfall across the northwestern Sierra Nevada during the 1985-2015 winter season. The North Cascades and South Cascades experience higher snowfall in January (compared to other winter months) at the elevation bands of 1000-1500 and 1500-2000 m with an average of 
TABLE 2. Exceedance probability of negative SWE changes ( $\mathrm{mm}$ ) during AR flooding events.

\begin{tabular}{ccccc}
\hline \hline Subregion & Latitudinal band & Flooding event date & Average negative SWE change (mm) & Exceedance probability (\%) \\
\hline North Cascades & $50^{\circ} \mathrm{N}$ & $1-3$ Dec 2007 & -21.5 & 11.5 \\
& $47.5^{\circ} \mathrm{N}$ & & -22.0 & 5.4 \\
South Cascades & $47.5^{\circ} \mathrm{N}$ & $17-19$ Nov 1996 & -31.1 & 3.0 \\
& $45^{\circ} \mathrm{N}$ & & -32.0 & 4.5 \\
Sierra Nevada & $42.5^{\circ} \mathrm{N}$ & & -30.3 & 3.6 \\
& $40^{\circ} \mathrm{N}$ & 26 Dec 1996-3 Jan 1997 & -29.4 & 4.4 \\
& $37.5^{\circ} \mathrm{N}$ & & -29.1 & 5.4 \\
& $35^{\circ} \mathrm{N}$ & & -53.3 & 0.2 \\
\hline
\end{tabular}

40 and $30 \mathrm{~mm}$, respectively. Such positive SWE changes associated with ARs were also observed by Neiman et al. (2008), who concluded that ARs predominantly increase SWE in the autumn and winter along both the northern and southern coast regions of the western United States.

In addition to snow accumulation, AR dates resulted in snowmelt (i.e., AR-related negative SWE changes) during the cold season months across all three subregions. The largest AR-related snowmelt $(-16 \mathrm{~mm})$ is in December at $50^{\circ} \mathrm{N}$ and averaged over the North Cascades at elevation band of 1000-1500 m. To further explore the impact of ARs on snowmelt, we investigated some of the largest floods in our record that are associated with AR events (Table 2). For each flooding event, we calculated the exceedance probability of the AR daily snowmelt from the upper 10th percentile daily negative SWE changes produced during AR and non-AR dates. As indicated in Table 2, the ARs in all three subregions resulted in snowmelt amounts that had exceedance probabilities (with one exception) of less than $5 \%$. Hence, snowmelt associated with ARs that brought copious amounts of rainfall contributes to major flooding events. However, given the lower magnitudes of snowmelt (roughly $25 \mathrm{~mm}$ compared to $\sim 150 \mathrm{~mm}$ of rainfall), rainfall is considered the primary contributor to such floods (Wayand et al. 2015). The effect of rainfall on snowmelt conditions was also reported for the Sierra
Nevada subregion by Guan et al. (2016) who found that $50 \%$ of the rain-on-snow occurrences between the water years (1998-2014) are associated with landfalling ARs.

\section{c. Dry versus wet years}

We evaluated AR-related precipitation and SWE change during dry versus wet years, where we defined dry years as having accumulated precipitation in the lower 10th percentile, and wet years as having accumulated precipitation in the upper 10th percentile during the winter months. Table 3 shows the six years in our record in each subregion that are defined as dry and wet years. As Table 3 indicates, the number of AR dates in the three subregions in wet years is larger than the number of AR dates during dry years. For instance, 594 AR dates were recorded along the North Cascades during the wet years compared to 322 AR dates during the dry years. Similarly, the South Cascades and Sierra Nevada are subjected to a higher number of AR events during wet years with 561 and 590 AR dates, respectively. The largest number of AR dates was during the wet year 1983 along the Sierra Nevada subregion with 120 AR dates. Given the larger number of AR dates in wet years, AR events can serve as the sources of major storms that end droughts in the western United States or "drought busters" as coined by Dettinger (2013). The AR role in this context is evident by the comparison of wet versus dry years over

TABLE 3. Dry and wet years identified for the three mountainous subregions based on total surface precipitation during the 67 -yr study period (1949-2015). The number in parentheses indicates the total number of AR dates identified in the cold season during dry and wet years.

\begin{tabular}{|c|c|c|c|c|c|}
\hline \multicolumn{3}{|c|}{ Dry years } & \multicolumn{3}{|c|}{ Wet years } \\
\hline North Cascades & South Cascades & Sierra Nevada & North Cascades & South Cascades & Sierra Nevada \\
\hline $1970(88)$ & $1962(74)$ & $1964(53)$ & $1953(100)$ & $1950(70)$ & $1952(76)$ \\
\hline 1977 (27) & 1977 (27) & $1972(69)$ & $1954(95)$ & $1954(95)$ & $1969(92)$ \\
\hline $1979(61)$ & $1992(72)$ & $1976(60)$ & $1967(100)$ & $1956(96)$ & $1974(102)$ \\
\hline $1985(47)$ & $1993(76)$ & $1977(27)$ & $1974(102)$ & $1974(102)$ & $1983(120)$ \\
\hline $1993(76)$ & $2001(23)$ & $1990(37)$ & $1999(96)$ & $1997(102)$ & $1986(87)$ \\
\hline $2001(23)$ & $2005(71)$ & $2014(67)$ & $2007(101)$ & $1999(96)$ & $1995(113)$ \\
\hline
\end{tabular}


three mountainous subregions in the western United States, where some dry years are followed by wet years. For example, the 1976-1977 drought years in the Sierra Nevada were followed by a very wet 1978 with 118 AR dates (compared to only 60 and 27 AR dates in 1976 and 1977, respectively).

For each subregion, we evaluated the precipitation and SWE change at the elevation band associated with the highest AR-related SWE change (as identified in section 3b). Accordingly, we used the elevation bands of $1000-1500,1500-2000$, and $2000-2500 \mathrm{~m}$ to represent the North Cascades, South Cascades, and Sierra Nevada subregions, respectively. The same elevation bands, selected for SWE change, resulted also in the maximum AR induced precipitation for each subregion (figure not shown). Figure 9 shows the range of precipitation amounts during dry and wet years for the North Cascades, South Cascades, and Sierra Nevada subregions. The box plot for each month represents the range of precipitation change depth produced by AR dates identified during dry or wet years. Comparing the three subregions during wet years, we notice higher precipitation amounts in the Sierra Nevada subregion, which decrease moving north. Across the latitudinal bands of the same subregion (figures not shown), no significant differences in precipitation amounts were noticed in the North and South Cascades, while for the Sierra Nevada subregion, precipitation amounts consistently increased toward northern latitudinal bands. The maximum interquartile range of precipitation amounts produced by AR dates is in January (170 AR dates during 6 wet years) at $40^{\circ} \mathrm{N}$ with $113 \mathrm{~mm}$.

In addition to a larger number of AR dates in wet years, it is also clear that wet year AR dates produce heavier precipitation compared to dry years during the cold season months. For instance, the median AR daily precipitation at $50^{\circ} \mathrm{N}$ for January is $40 \mathrm{~mm}$ in wet years compared to median precipitation of only $13 \mathrm{~mm}$ during January of dry years. Such differences are attributable to differences in both the number of AR events and AR precipitation intensities between wet and dry years. The differences in the intensity of AR precipitation between dry and wet years agree in general with the results of Dettinger (2016, his Fig. 5) who showed that the wettest $5 \%$ of precipitation events (not segregated into AR vs non-AR, however the largest events are disproportionately associated with ARs) in Northern California account for a higher fraction of total (water year) precipitation in wet years than in dry years.

The differences in AR-induced precipitation between dry and wet years become much smaller in February and March. In particular, for the North Cascades dry-year ARs produce precipitation with very comparable values
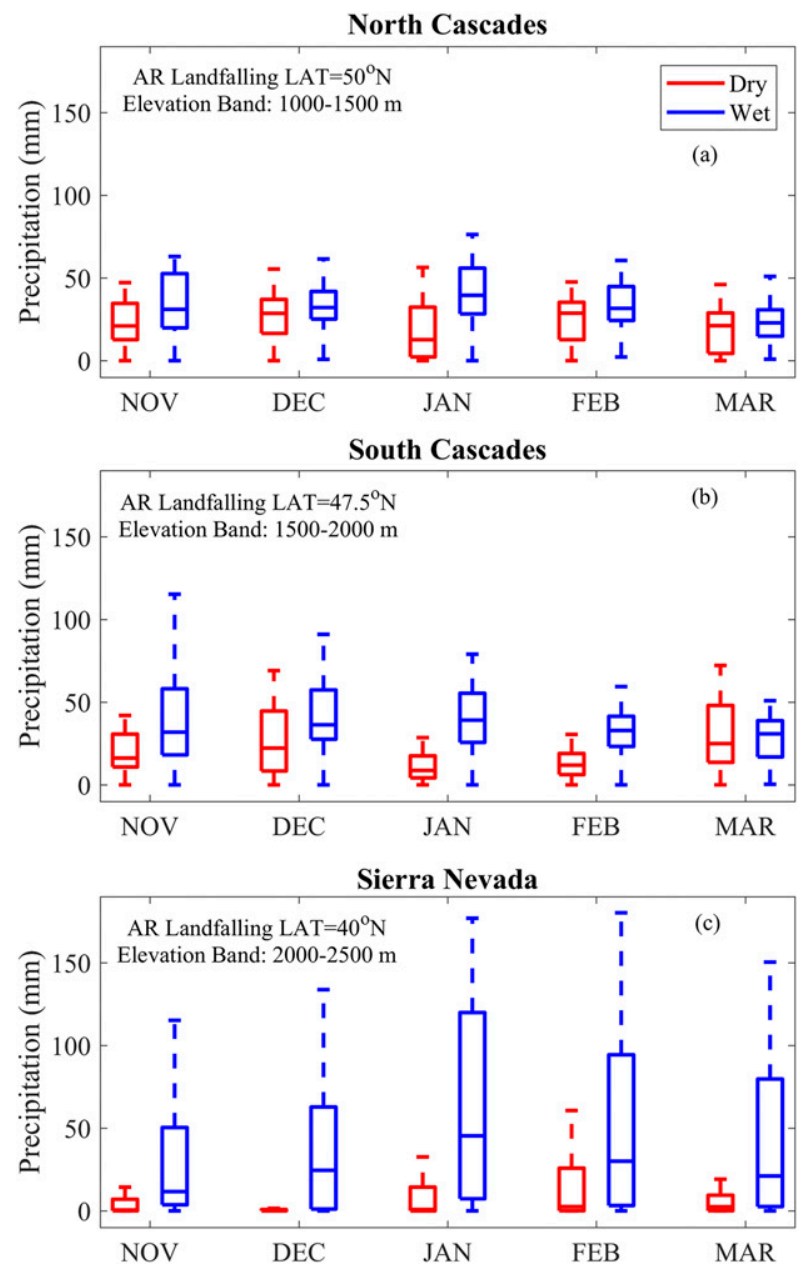

FIG. 9. Daily precipitation associated with AR dates during dry and wet years in three mountainous subregions (North Cascades, South Cascades, and Sierra Nevada). On each box, the central mark indicates the median depth, and the bottom and top edges of the box indicate the 25th and 75th percentiles (or interquartile range), respectively. The whiskers of the box extend to the most extreme data points not considered outliers (outlier points are not shown in the figure).

to wet years (Fig. 9). For example, the median AR daily precipitation produced in March at $50^{\circ} \mathrm{N}$ over the North Cascades is $22.9 \mathrm{~mm}$ during wet years compared to $21.2 \mathrm{~mm}$ during dry years. Furthermore, when comparing between northern and southern ARs during dry years, Fig. 9c indicates that southern ARs falling on Sierra Nevada produce much less intense precipitation with a median precipitation less than $5 \mathrm{~mm}$ in all cold season months.

Similar patterns are also present for positive SWE changes in the three subregions where higher snow accumulation is observed in the wintertime months (December-March) during wet years (Figs. 10-12). The highest snow accumulation is produced by the ARs at 
Positive SWE Change (Snowfall)
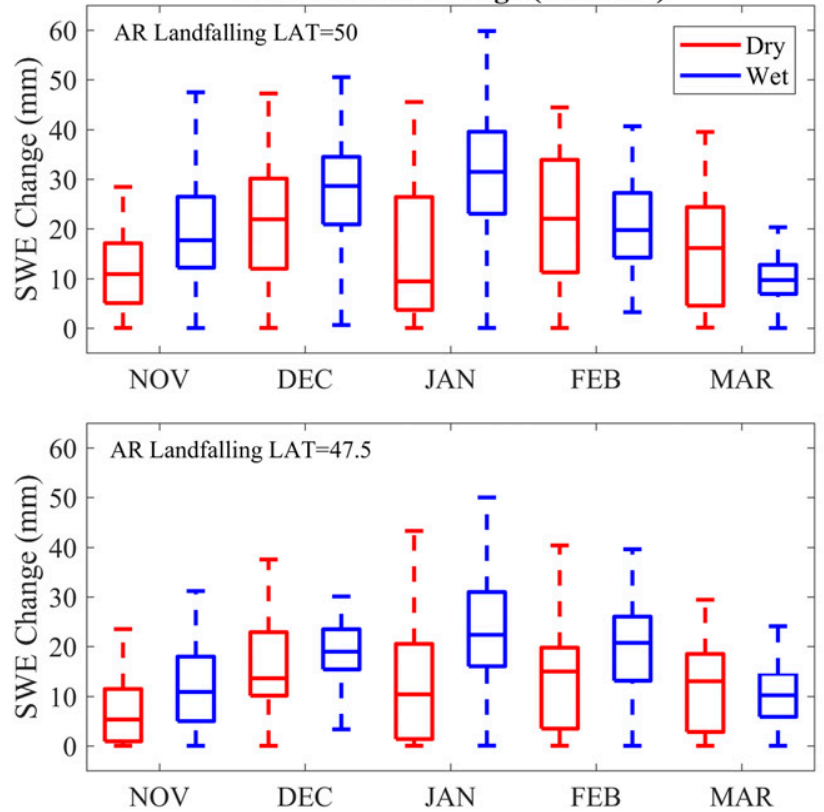

Negative SWE Change (Snowmelt)
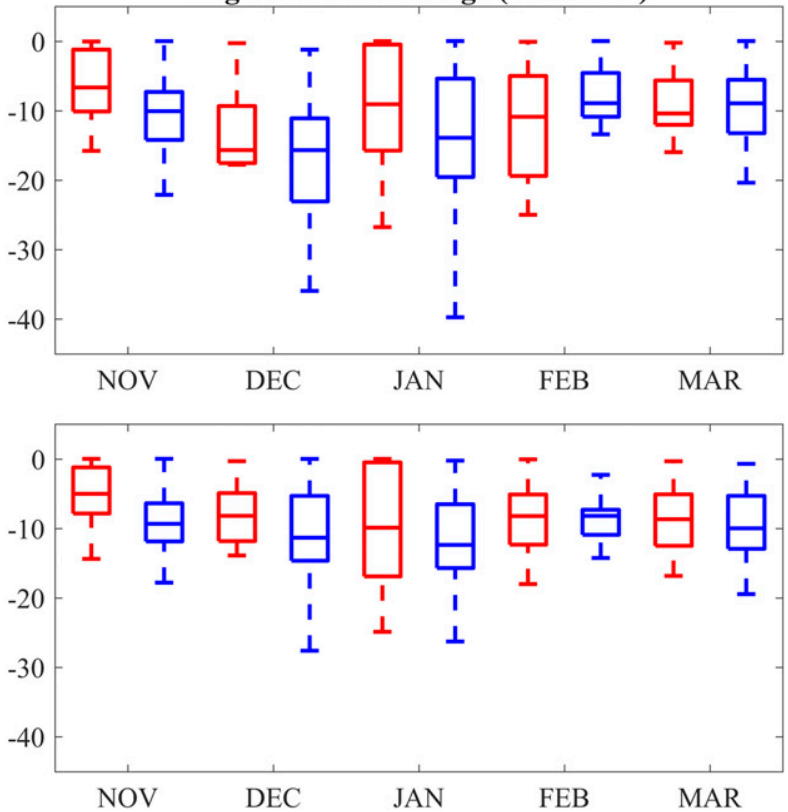

FIG. 10. Daily SWE change induced by AR dates in North Cascades at the elevation band of 1000-1500 m and for different AR landfalling latitudes during dry and wet years (for each month, the left and right boxplots represent the precipitation during dry and wet years, respectively).

$40^{\circ} \mathrm{N}$ where the median positive SWE change is about $44.5 \mathrm{~mm}$ in January with an interquartile range of $96 \mathrm{~mm}$. The differences between wet and dry years in the magnitudes of positive SWE changes are smaller for the North and South Cascades (Figs. 11, 12). In addition, the AR events in the North Cascades in March during dry years resulted in higher snow accumulation compared to wet years. For example, the median of positive SWE changes during March for ARs with landfall at $50^{\circ} \mathrm{N}$ during dry years is $16 \mathrm{~mm}$ (interquartile range $=20 \mathrm{~mm}$ ) compared to $10 \mathrm{~mm}$ (interquartile range $=6 \mathrm{~mm}$ ) during wet years. The fraction of (number of) days with positive SWE change (fraction from all AR dates during the dry or wet year) is higher in the North Cascades compared to the South Cascades and Sierra Nevada. For instance, the North Cascades subregion has an average of $74 \%$ of AR dates during wet years with positive SWE change compared to only $51 \%$ over the Sierra Nevada. The negative SWE changes during dry and wet years are comparable although some parts of wet year winters have higher snowmelt, for example, ARs in November at $42.5^{\circ} \mathrm{N}$ over the South Cascades and January at $37.5^{\circ} \mathrm{N}$ over the Sierra Nevada subregion. Earlier snowmelt (NovemberJanuary) during ARs in wet years occurs in the North and South Cascades subregions and could also explain the existence of rain-on-snow conditions during AR dates. Progressing southward in the Sierra Nevada subregion, a gradual decrease in positive SWE changes occurs (similar to the precipitation pattern). Snowmelt becomes noticeably higher than snow accumulation at the lowest AR landfalling latitude in the Sierra Nevada $\left(35^{\circ} \mathrm{N}\right)$. For example, ARs at landfalling latitude $35^{\circ} \mathrm{N}$ resulted in a median daily snowmelt of $14 \mathrm{~mm}$ compared to only $3 \mathrm{~mm}$ of snow accumulation in January of wet years.

\section{d. Warm AR events}

We investigated the effects of surface air temperatures associated with AR events on the daily precipitation depth and SWE change by considering the largest warm AR events $(20 \%$ of AR dates with the highest surface air temperature). Figure 13 shows the precipitation at different landfalling latitudes for each of the three subregions during these warm events. We also compare the precipitation produced during these warm events (the red box plots in Fig. 13) with that produced by all upper 10th percentile AR daily precipitation (the blue box plots in Fig. 13). As a subset of all the upper 10th percentile daily precipitation, warm AR events are associated with the most extreme precipitation for the three subregions. This is indicated in Fig. 13, where the interquartile range for warm event precipitation lies above the median of all the upper 10th percentile daily precipitation. The warm AR events resulted in higher precipitation along the Sierra Nevada subregion (with exception of the most southern landfalling latitude of $35^{\circ} \mathrm{N}$ ) compared to the North and South Cascades 

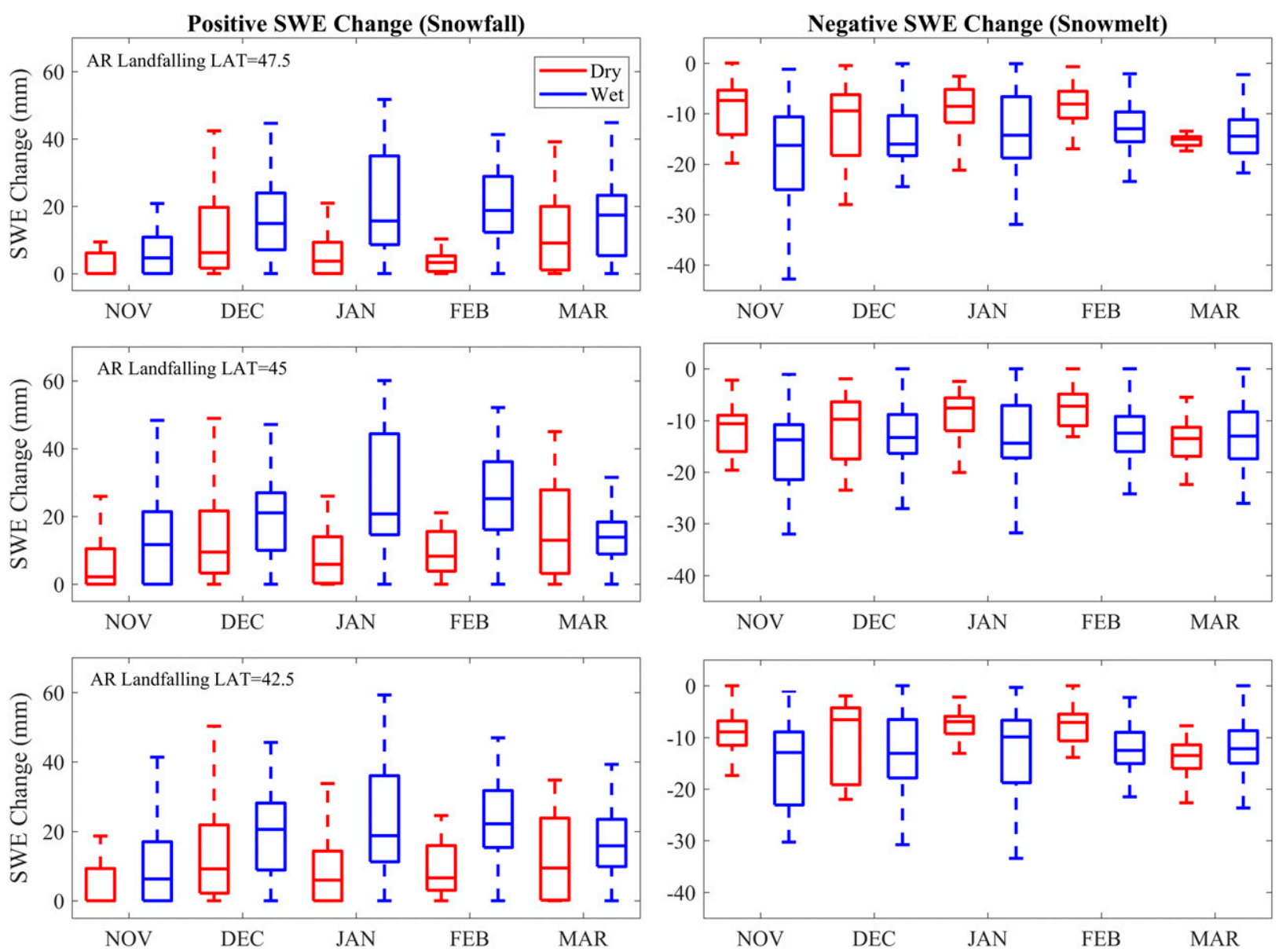

FIG. 11. As in Fig. 10, but for the South Cascades at the elevation band of 1500-2000 m.

subregions. This is attributed to warmer south coast ARs that contain more water vapor as concluded by Neiman et al. (2008). For instance, the largest precipitation is produced at $40^{\circ} \mathrm{N}$ in the Sierra Nevada subregion with a median depth of $150 \mathrm{~mm}$ compared to $100 \mathrm{~mm}$ at $42.5^{\circ} \mathrm{N}$ (the largest median precipitation over the North and South Cascades). The high precipitation amounts produced by warm AR events, especially those falling at southern latitudinal bands, are consistent with Leung and Qian (2009) who concluded large AR-induced precipitation and warmer temperature over most of the mountain ranges in western United States.

Unsurprisingly, warm AR events have lower median SWE accumulation (except for $35^{\circ}$ and $40^{\circ} \mathrm{N}$ over the Sierra Nevada) compared to the upper 10th percentile AR daily positive SWE changes (Fig. 14). The largest median positive SWE change occurs for ARs at $40^{\circ} \mathrm{N}$ with $136 \mathrm{~mm}$. The average surface temperature for warm landfalling ARs at this latitude is $-0.15^{\circ} \mathrm{C}$, which is the lowest average temperature during the warm $\mathrm{AR}$ dates with snow accumulation. The highest average temperature $\left(2.60^{\circ} \mathrm{C}\right)$ is along the North Cascades at $47.5^{\circ} \mathrm{N}$ with the lowest median snow accumulation of $45 \mathrm{~mm}$. Along most of the AR landfalling latitudes, warm AR dates resulted in higher snowmelt rates compared to all upper 10th percentile AR daily negative SWE changes (Fig. 14). The highest AR-related negative SWE changes (median $-41 \mathrm{~mm}$ and $75 \mathrm{th}$ percentile $-43 \mathrm{~mm}$ ) are produced by warm AR dates over the South Cascades at $47.5^{\circ} \mathrm{N}$ with an average surface temperature of $7.7^{\circ} \mathrm{C}$.

\section{Conclusions}

We utilized hydrometeorological outputs retrieved from dynamically downscaled atmospheric reanalyses (NCEP-NCAR) using the WRF mesoscale numerical weather prediction model to characterize precipitation amounts and snowpack changes during atmospheric river dates over the period 1949-2015. We focus on three subregions of the coastal western United States: North 

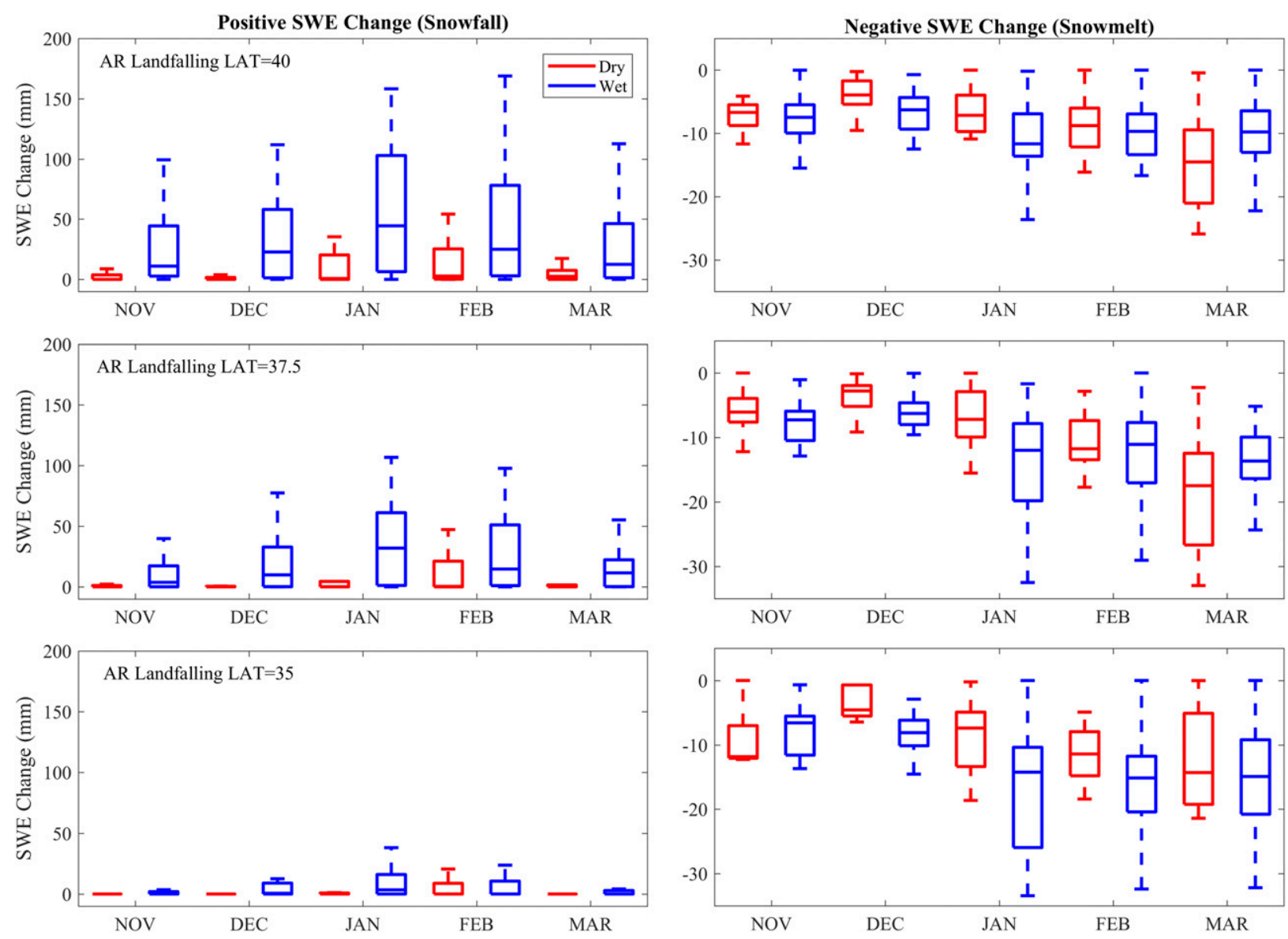

FIG. 12. As in Fig. 10, but for the Sierra Nevada at the elevation band of 2000-2500 m.

Cascades, South Cascades, and Sierra Nevada. We find the following:

1) Landfalling ARs in the southern part of our domain (Sierra Nevada subregion) resulted in higher precipitation amounts than in the two northern subregions, although more AR events occur on average in the northern subregions. At all southern landfalling latitudes (south of $42.5^{\circ} \mathrm{N}$ ), more extreme events occur in January and February than earlier in the winter.

2) The highest positive SWE change induced by ARs in all subregions occurs in January, with the highest snow accumulations occurring in the Sierra Nevada subregion. AR-related negative SWE changes generally occur during the cold months. Some of the most extreme snowmelt conditions accompanied major flooding events. High AR-related snowmelt explains the early snowmelt and the potential existence of rainon-snow (ROS) conditions associated with AR dates.

3) ARs play an important role as drought buster as evident by the comparison of the statistics of ARs in wet versus dry years across the three subregions. In the Sierra Nevada subregion, ARs during wet years are not only greater in number than in dry years, but they also produce heavier precipitation and snow accumulation per event compared to dry years. In contrast, precipitation amounts during AR events are very comparable in wet and dry years in the two northern subregions, the main difference is that the number of AR dates is smaller during dry years.

4) Most AR extreme precipitation events in northern latitudes are produced during warm AR dates when compared to all upper 10th percentile precipitation. Such warm AR events resulted in lower SWE accumulation (higher snowmelt rates), especially toward the northern latitudes over the South and North Cascades subregions.

The implications of AR characterization presented in this study are clearly evident in water management, flood and drought risk assessment, and operational weather forecasting. For instance, better management strategies of water resources in western United States 


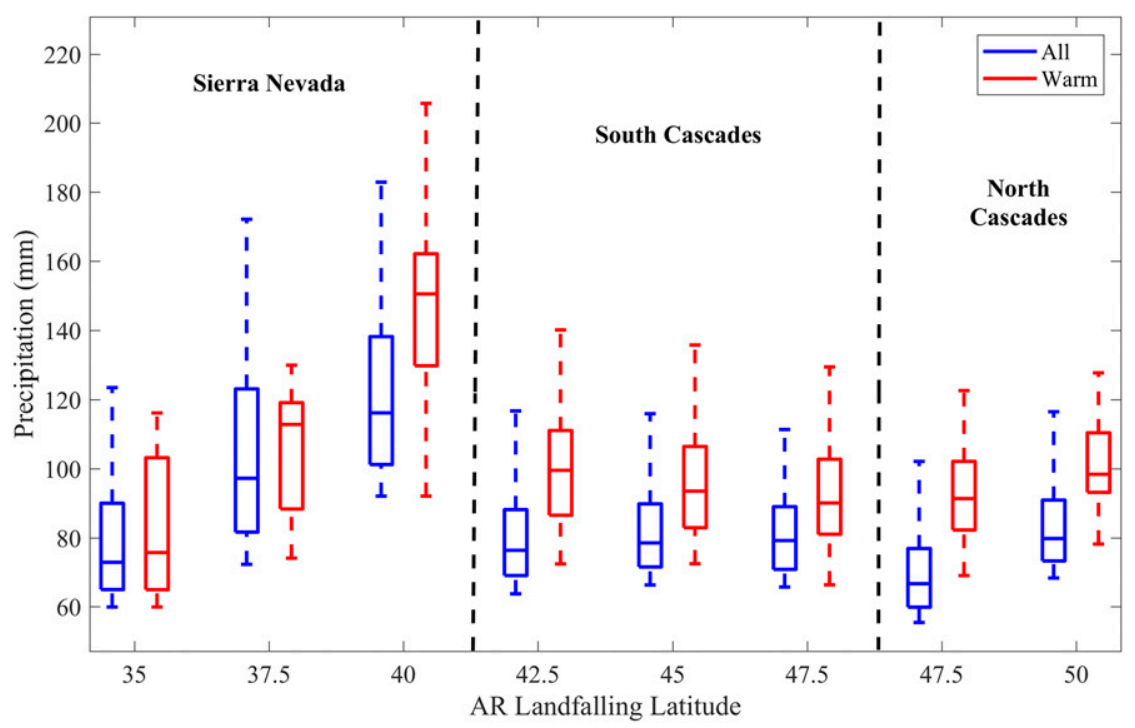

FIG. 13. Boxplot of the upper 10th percentile daily precipitation considering all AR dates and only warm events for each mountainous subregion at different AR landfalling latitudes.

are recommended to cope with the expected increase in AR induced precipitation with changing climate. In addition, future efforts will be essential to investigate the impacts of ARs precipitation on modeling the water budget of western United States basins and how reservoir operations can be altered based on AR forecasting. Furthermore, highlighting the spatial differences in areas impacted by AR dates can be a key input for the
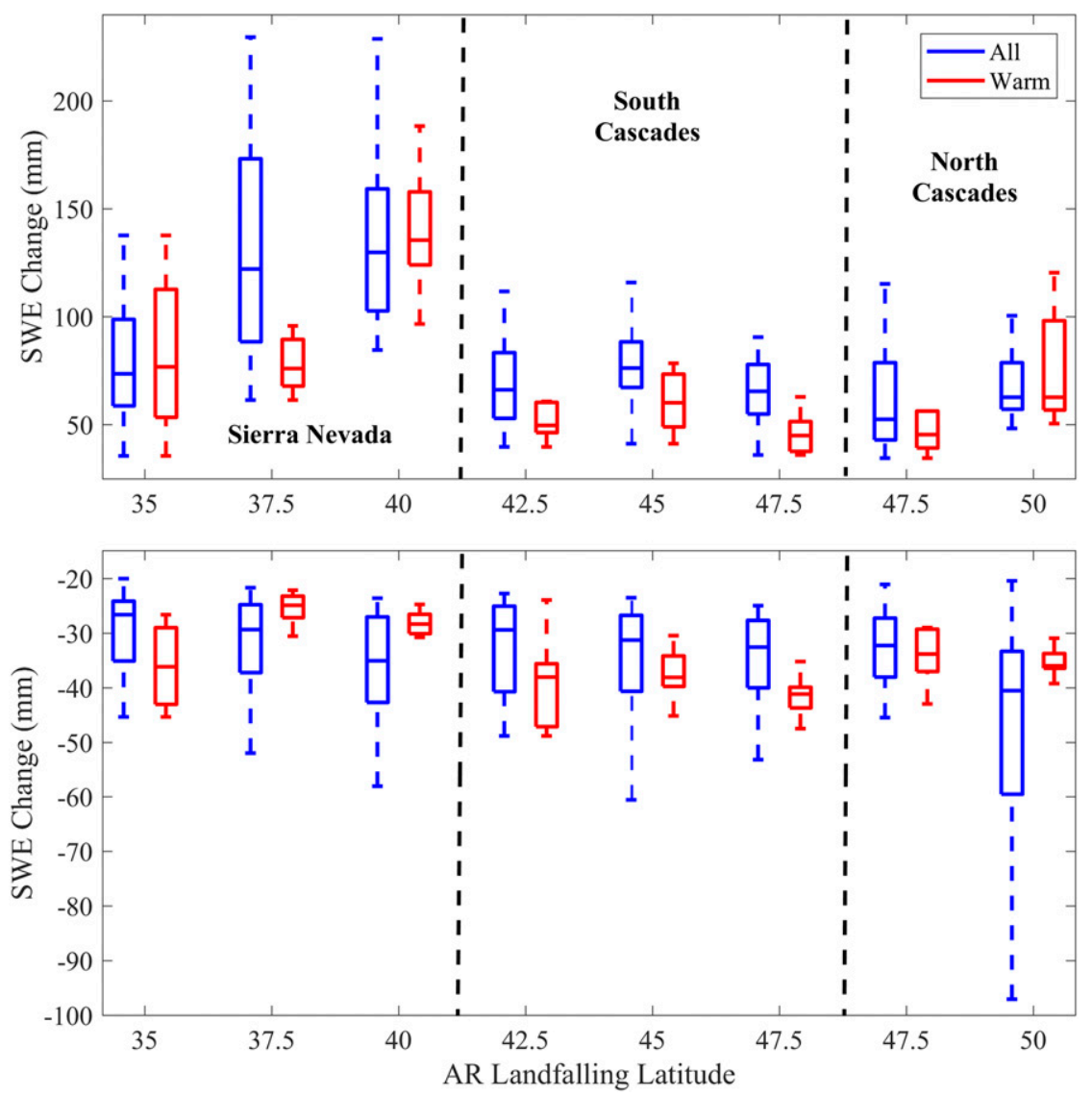

FIG. 14. Boxplot of the upper 10th percentile daily positive and negative SWE change considering all AR dates and only warm events for each mountainous subregion at different AR landfalling latitudes. 
future development of atmospheric river observatory (ARO) systems. Such systems are currently being developed to detect and monitor the atmospheric forcing that leads to heavy precipitation along the coastal range and inland mountains (Neiman et al. 2009; White et al. 2012; Ralph et al. 2014).

Acknowledgments. This study was performed under support from the Strategic Environmental Research and Development Program (SERDP)-Project RC-2513 granted to the University of California, Los Angeles, and an associated subcontract to the University of Washington. The first author was also supported by NASA Grant NNX16AC63G to the University of Washington. The NCEP-NCAR AR catalog used in this paper can be obtained from https://ucla.box.com/ ARcatalog. The WRF downscaled reanalysis data are available on the Dropbox folder: https://www.dropbox. com/home/Public/SERDP/Northwest.

\section{REFERENCES}

Amante, C., and B. W. Eakins, 2009: ETOPO1 Global Relief Model converted to PanMap layer format. PANGAEA, https://doi.org/10.1594/PANGAEA.769615.

Bao, J. W., S. A. Michelson, P. J. Neiman, F. M. Ralph, and J. M. Wilczak, 2006: Interpretation of enhanced integrated water vapor bands associated with extratropical cyclones: Their formation and connection to tropical moisture. Mon. Wea. Rev., 134, 1063-1080, https://doi.org/10.1175/MWR3123.1.

Barth, N. A., G. Villarini, M. A. Nayak, and K. White, 2017: Mixed populations and annual flood frequency estimates in the western United States: The role of atmospheric rivers. Water Resour. Res., 53, 257-269, https://doi.org/10.1002/ 2016WR019064.

Browning, K. A., and C. W. Pardoe, 1973: Structure of low-level jet streams ahead of mid-latitude cold fronts. Quart. J. Roy. Meteor. Soc., 99, 619-638, https://doi.org/10.1002/qj.49709942204.

Cayan, D. R., M. D. Dettinger, S. A. Kammerdiener, J. M. Caprio, and D. H. Peterson, 2001: Changes in the onset of spring in the western United States. Bull. Amer. Meteor. Soc., 82, 399-415, https://doi.org/10.1175/1520-0477(2001) 082<0399:CITOOS $>2.3$.CO;2.

Chen, X., and F. Hossain, 2016: Revisiting extreme storms of the past 100 years for future safety of large water management infrastructures. Earth's Future, 4, 306-322, https://doi.org/ 10.1002/2016EF000368.

,-- , and L. R. Leung, 2017: Establishing a numerical modeling framework for hydrologic engineering analyses of extreme storm events. J. Hydrol. Eng., 22, 04017016, https:// doi.org/10.1061/(ASCE)HE.1943-5584.0001523.

Daly, C., R. P. Neilson, and D. L. Phillips, 1994: A statisticaltopographic model for mapping climatological precipitation over mountainous terrain. J. Appl. Meteor., 33, 140-158, https:// doi.org/10.1175/1520-0450(1994)033<0140:ASTMFM>2.0.CO;2.

Dettinger, M., 2011: Climate change, atmospheric rivers, and floods in California-A multimodel analysis of storm frequency and magnitude changes. J. Amer. Water Resour. Assoc., 47, 514-523, https://doi.org/10.1111/j.1752-1688.2011.00546.x.
_ 2013: Atmospheric rivers as drought busters on the U.S. West Coast. J. Hydrometeor., 14, 1721-1732, https://doi.org/10.1175/ JHM-D-13-02.1.

- , 2016: Historical and future relations between large storms and droughts in California. San Francisco Estuary Watershed Sci., 14 (2), https://doi.org/10.15447/sfews.2016v14iss2art1.

— , F. M. Ralph, T. Das, P. J. Neiman, and D. R. Cayan, 2011: Atmospheric rivers, floods and the water resources of California. Water, 3, 445-478, https://doi.org/10.3390/w3020445. , - - and J. J. Rutz, 2018: Empirical return periods of the most intense vapor transports during historical atmospheric river landfalls on the U.S. West Coast. J. Hydrometeor., 19, 1363-1377, https://doi.org/10.1175/JHM-D-17-0247.1.

Eiras-Barca, J., A. M. Ramos, J. G. Pinto, R. M. Trigo, M. L. Liberato, and G. Miguez-Macho, 2018: The concurrence of atmospheric rivers and explosive cyclogenesis in the North Atlantic and North Pacific basins. Earth Syst. Dyn., 9, 91-102, https://doi.org/10.5194/esd-9-91-2018.

Eldardiry, H., E. Habib, and Y. Zhang, 2015: On the use of radarbased quantitative precipitation estimates for precipitation frequency analysis. J. Hydrol., 531, 441-453, https://doi.org/ 10.1016/j.jhydrol.2015.05.016.

Gershunov, A., T. Shulgina, F. M. Ralph, D. A. Lavers, and J. J. Rutz, 2017: Assessing the climate-scale variability of atmospheric rivers affecting western North America. Geophys. Res. Lett., 44, 7900-7908, https://doi.org/10.1002/2017GL074175.

Griffin, D., and K. J. Anchukaitis, 2014: How unusual is the 20122014 California drought? Geophys. Res. Lett., 41, 9017-9023, https://doi.org/10.1002/2014GL062433.

Guan, B., and D. E. Waliser, 2015: Detection of atmospheric rivers: Evaluation and application of an algorithm for global studies. J. Geophys. Res. Atmos., 120, 12 514-12 535, https://doi.org/ 10.1002/2015JD024257.

— N. P. Molotch, D. E. Waliser, E. J. Fetzer, and P. J. Neiman, 2010: Extreme snowfall events linked to atmospheric rivers and surface air temperature via satellite measurements. Geophys. Res. Lett., 37, L20401, https://doi.org/10.1029/ 2010 GL044696.

—, D. E. Waliser, F. M. Ralph, E. J. Fetzer, and P. J. Neiman, 2016: Hydrometeorological characteristics of rain-on-snow events associated with atmospheric rivers. Geophys. Res. Lett., 43, 2964-2973, https://doi.org/10.1002/2016GL067978.

Hagos, S. M., L. R. Leung, J. H. Yoon, J. Lu, and Y. Gao, 2016: A projection of changes in landfalling atmospheric river frequency and extreme precipitation over western North America from the Large Ensemble CESM simulations. Geophys. Res. Lett., 43, 1357-1363, https://doi.org/10.1002/ 2015 GL067392.

Hong, S. Y., Y. Noh, and J. Dudhia, 2006: A new vertical diffusion package with an explicit treatment of entrainment processes. Mon. Wea. Rev., 134, 2318-2341, https://doi.org/10.1175/ MWR3199.1.

Hosking, J. R., and J. Wallis, 1997: Regional Frequency Analysis: An Approach Based on L-Moments. Cambridge University Press, 242 pp.

Hu, X. M., M. Xue, R. A. McPherson, E. Martin, D. H. Rosendahl, and L. Qiao, 2018: Precipitation dynamical downscaling over the Great Plains. J. Adv. Model. Earth Syst., 10, 421-447, https://doi.org/10.1002/2017MS001154.

Huning, L. S., B. Guan, D. E. Waliser, and D. P. Lettenmaier, 2019: Sensitivity of seasonal snowfall attribution to atmospheric rivers and their reanalysis-based detection. Geophys. Res. Lett., 46, 794-803. https://doi.org/10.1029/2018GL080783. 
Jordan, R., 1991: A one-dimensional temperature model for a snow cover: Technical documentation for SNTERERM.89. Special Rep. 91-16, Cold Region Research and Engineers Laboratory, U.S. Army Corps of Engineers, Hanover, NH, 61 pp.

Kain, J., 2004: The Kain-Fritsch convective parameterization: An update. J. Appl. Meteor., 43, 170-181, https://doi.org/10.1175/ 1520-0450(2004)043<0170:TKCPAU > 2.0.CO;2.

_ , and J. Fritsch, 1990: A one-dimensional entraining/detraining plume model and its application in convective parameterization. J. Atmos. Sci., 47, 2784-2802, https://doi.org/10.1175/ 1520-0469(1990)047<2784:AODEPM>2.0.CO;2.

_ and - 1993: Convective parameterization for mesoscale models: The Kain-Fritsch scheme. The Representation of Cumulus Convection in Numerical Models, Meteor. Monogr., No. 46, Amer. Meteor. Soc., 165-170.

Kalnay, E., and Coauthors, 1996: The NCEP/NCAR 40-Year Reanalysis Project. Bull. Amer. Meteor. Soc., 77, 437-471, https:// doi.org/10.1175/1520-0477(1996)077<0437:TNYRP>2.0.CO;2.

Kistler, R., and Coauthors, 2001: The NCEP-NCAR 50-year reanalysis: Monthly means CD-ROM and documentation. Bull. Amer. Meteor. Soc., 82, 247-267, https://doi.org/10.1175/ 1520-0477(2001)082<0247:TNNYRM > 2.3.CO;2.

Konrad, C. P., and M. D. Dettinger, 2017: Flood runoff in relation to water vapor transport by atmospheric rivers over the Western United States, 1949-2015. Geophys. Res. Lett., 44, 11 456-11 462, https://doi.org/10.1002/2017GL075399.

Lamjiri, M. A., M. D. Dettinger, F. M. Ralph, and B. Guan, 2017: Hourly storm characteristics along the US West Coast: Role of atmospheric rivers in extreme precipitation. Geophys. Res. Lett., 44, 7020-7028, https://doi.org/10.1002/2017GL074193.

Leung, L. R., and Y. Qian, 2009: Atmospheric rivers induced heavy precipitation and flooding in the western US simulated by the WRF regional climate model. Geophys. Res. Lett., 36, L03820, https://doi.org/10.1029/2008GL036445.

Liang, X., D. P. Lettenmaier, E. F. Wood, and S. J. Burges, 1994: A simple hydrologically based model of land surface water and energy fluxes for general circulation models. J. Geophy. Res., 99, 14 415-14 428, https://doi.org/10.1029/94JD00483.

Liu, C., and Coauthors, 2017: Continental-scale convectionpermitting modeling of the current and future climate of North America. Climate Dyn., 49, 71-95, https://doi.org/ 10.1007/s00382-016-3327-9.

Livneh, B., E. A. Rosenberg, C. Lin, B. Nijssen, V. Mishra, K. M. Andreadis, E. P. Maurer, and D. P. Lettenmaier, 2013: A longterm hydrologically based dataset of land surface fluxes and states for the conterminous United States: Update and extensions. J. Climate, 26, 9384-9392, https://doi.org/10.1175/ JCLI-D-12-00508.1.

Lorente-Plazas, R., T. P. Mitchell, G. Mauger, and E. P. Salathé Jr., 2018: Local enhancement of extreme precipitation during atmospheric rivers as simulated in a regional climate model. J. Hydrometeor., 19, 1429-1446, https://doi.org/10.1175/JHMD-17-0246.1.

Maurer, E. P., A. W. Wood, J. C. Adam, D. P. Lettenmaier, and B. Nijssen, 2002: A long-term hydrologically based dataset of land surface fluxes and states for the conterminous United States. J. Climate, 15, 3237-3251, https://doi.org/10.1175/ 1520-0442(2002)015<3237:ALTHBD>2.0.CO;2.

McMahon, G., S. M. Gregonis, S. W. Waltman, J. M. Omernik, T. D. Thorson, J. A. Freeouf, A. H. Rorick, and J. E. Keys, 2001: Developing a spatial framework of common ecological regions for the conterminous United States. Environ. Manage., 28, 293-316, https://doi.org/10.1007/s0026702429.
Morrison, H., G. Thompson, and V. Tatarskii, 2009: Impact of cloud microphysics on the development of trailing stratiform precipitation in a simulated squall line: Comparison of oneand two-moment schemes. Mon. Wea. Rev., 137, 991-1007, https://doi.org/10.1175/2008MWR2556.1.

Nayak, M. A., G. Villarini, and D. A. Lavers, 2014: On the skill of numerical weather prediction models to forecast atmospheric rivers over the central United States. Geophys. Res. Lett., 41, 4354-4362, https://doi.org/10.1002/2014GL060299.

Neiman, P. J., F. M. Ralph, G. A. Wick, J. D. Lundquist, and M. D. Dettinger, 2008: Meteorological characteristics and overland precipitation impacts of atmospheric rivers affecting the West Coast of North America based on eight years of SSM/I satellite observations. J. Hydrometeor., 9, 22-47, https://doi.org/ 10.1175/2007JHM855.1.

, A. B. White, F. M. Ralph, D. J. Gottas, and S. I. Gutman, 2009: A water vapour flux tool for precipitation forecasting. Proc. Inst. Civ. Eng.: Water Manage., 162, 83-94, https:// doi.org/10.1680/wama.2009.162.2.83.

, L. J. Schick, F. M. Ralph, M. Hughes, and G. A. Wick, 2011: Flooding in western Washington: The connection to atmospheric rivers. J. Hydrometeor., 12, 1337-1358, https://doi.org/ 10.1175/2011JHM1358.1.

Niu, G. Y., and Coauthors, 2011: The community Noah land surface model with multiparameterization options (Noah-MP): 1. Model description and evaluation with local-scale measurements. J. Geophys. Res., 116, D12109, https://doi.org/10.1029/ 2010JD015139.

Omernik, J. M., 2004: Perspectives on the nature and definition of ecological regions. Environ. Manage., 34, S27-S38, https:// doi.org/10.1007/s00267-003-5197-2.

Overeem, A., T. A. Buishand, and I. Holleman, 2009: Extreme rainfall analysis and estimation of depth-duration-frequency curves using weather radar. Water Resour. Res., 45, W10424, https://doi.org/10.1029/2009WR007869.

Peterson, T. C., X. Zhang, M. Brunet-India, and J. L. VázquezAguirre, 2008: Changes in North American extremes derived from daily weather data. J. Geophys. Res., 113, D07113, https://doi.org/10.1029/2007JD009453.

Ralph, F. M., and M. D. Dettinger, 2011: Storms, floods, and the science of atmospheric rivers. Eos, Trans. Amer. Geophys. Union, 92, 265-266, https://doi.org/10.1029/2011EO320001.

——, and ——, 2012: Historical and national perspectives on extreme West Coast precipitation associated with atmospheric rivers during December 2010. Bull. Amer. Meteor. Soc., 93, 783-790, https://doi.org/10.1175/BAMS-D11-00188.1.

, P. J. Neiman, and G. A. Wick, 2004: Satellite and CALJET aircraft observations of atmospheric rivers over the eastern North Pacific Ocean during the winter of 1997/98. Mon. Wea. Rev., 132, 1721-1745, https://doi.org/10.1175/1520-0493(2004) 132<1721:SACAOO $>2.0 . C O ; 2$.

,,--- , S. I. Gutman, M. D. Dettinger, D. R. Cayan, and A. B. White, 2006: Flooding on California's Russian River: Role of atmospheric rivers. Geophys. Res. Lett., 33, L13801, https://doi.org/10.1029/2006GL026689.

, T. Coleman, P. J. Neiman, R. J. Zamora, and M. D. Dettinger, 2013: Observed impacts of duration and seasonality of atmospheric-river landfalls on soil moisture and runoff in coastal northern California. J. Hydrometeor., 14, 443-459, https://doi.org/10.1175/JHM-D-12-076.1.

- and Coauthors, 2014: A vision for future observations for western U.S. extreme precipitation and flooding. J. Contemp. 
Water Res. Educ., 153, 16-32, https://doi.org/10.1111/j.1936704X.2014.03176.x.

, M. D. Dettinger, M. M. Cairns, T. J. Galarneau, and J. Eylander, 2018: Defining "atmospheric river": How the Glossary of Meteorology helped resolve a debate. Bull. Amer. Meteor. Soc., 99, 837-839, https://doi.org/10.1175/BAMS-D17-0157.1.

, and Coauthors, 2019: ARTMIP-early start comparison of atmospheric river detection tools: How many atmospheric rivers hit northern California's Russian River watershed? Climate Dyn., 52, 4973-4994, https://doi.org/10.1007/s00382-018-4427-5.

Regonda, S. K., B. Rajagopalan, M. Clark, and J. Pitlick, 2005: Seasonal cycle shifts in hydroclimatology over the western United States. J. Climate, 18, 372-384, https://doi.org/10.1175/ JCLI-3272.1.

Rosen, J., 2017: California rains put spotlight on atmospheric rivers. Science, 355, 787, https://doi.org/10.1126/science.355.6327.787.

Rutz, J. J., W. J. Steenburgh, and F. M. Ralph, 2014: Climatological characteristics of atmospheric rivers and their inland penetration over the western United States. Mon. Wea. Rev., 142, 905-921, https://doi.org/10.1175/MWR-D-13-00168.1.

Shields, C. A., and Coauthors, 2018: Atmospheric River Tracking Method Intercomparison Project (ARTMIP): Project goals and experimental design. Geosci. Model Dev., 11, 2455-2474, https://doi.org/10.5194/gmd-11-2455-2018.

Skamarock, W. C., J. B. Klemp, J. Dudhia, D. O. Gill, D. M. Barker, W. Wang, and J. G. Powers, 2005: A description of the Advanced Research WRF version 2. NCAR Tech. Note NCAR/ TN-468+STR, 88 pp., https://doi.org/10.5065/D6DZ069T.

Swain, D. L., M. Tsiang, M. Haugen, D. Singh, A. Charland, B. Rajaratnam, and N. S. Diffenbaugh, 2014: The extraordinary California drought of 2013/2014: Character, context, and the role of climate change [in "Explaining Extreme Events of 2013 from a Climate Perspective"]. Bull. Amer. Meteor. Soc., 95 (9), S3-S6, https://doi.org/10.1175/1520-0477-95.9.S1.1.

Trujillo, E., and N. P. Molotch, 2014: Snowpack regimes of the western United States. Water Resour. Res., 50, 5611-5623, https://doi.org/10.1002/2013WR014753.

Wang, J., and V. R. Kotamarthi, 2014: Downscaling with a nested regional climate model in near-surface fields over the contiguous United States. J. Geophys. Res. Atmos., 119, 8778-8797, https://doi.org/10.1002/2014JD021696.

Wayand, N. E., J. D. Lundquist, and M. P. Clark, 2015: Modeling the influence of hypsometry, vegetation, and storm energy on snowmelt contributions to basins during rain-on-snow floods. Water Resour. Res., 51, 8551-8569, https://doi.org/10.1002/ 2014WR016576.

White, A. B., and Coauthors, 2012: NOAA's rapid response to the Howard A. Hanson Dam flood risk management crisis. Bull. Amer. Meteor. Soc., 93, 189-207, https://doi.org/10.1175/ BAMS-D-11-00103.1.

Yang, Z.-L., and Coauthors, 2011: The community Noah land surface model with multiparameterization options (NoahMP): 2. Evaluation over global river basins. J. Geophys. Res., 116, D12110, https://doi.org/10.1029/2010JD015140.

Young, A. M., K. T. Skelly, and J. M. Cordeira, 2017: High-impact hydrologic events and atmospheric rivers in California: An investigation using the NCEI Storm Events Database. Geophys. Res. Lett., 44, 3393-3401, https://doi.org/10.1002/ 2017GL073077.

Zhu, Y., and R. E. Newell, 1998: A proposed algorithm for moisture fluxes from atmospheric rivers. Mon. Wea. Rev., 126, 725-735, https://doi.org/10.1175/1520-0493(1998)126<0725: APAFMF $>2.0 . \mathrm{CO} ; 2$. 